AperTO - Archivio Istituzionale Open Access dell'Università di Torino

IPRs and international knowledge flows: Evidence from six large emerging countries

This is a pre print version of the following article:

Original Citation:

Availability:

This version is available http://hdl.handle.net/2318/124323

since

Terms of use:

Open Access

Anyone can freely access the full text of works made available as "Open Access". Works made available under a Creative Commons license can be used according to the terms and conditions of said license. Use of all other works requires consent of the right holder (author or publisher) if not exempted from copyright protection by the applicable law. 


\title{
IPRs and international knowledge flows: Evidence from six large emerging countries
}

\author{
Fabio Montobbio ${ }^{\oplus}$, Annalisa Primi $^{\varnothing}$, Valerio Sterzi $\oint^{\oplus}$ \\ ${ }^{\otimes}$ Dept. of Economics "S. Cognetti de Martiis", University of Turin, Via Po 53, 10124 \\ Torino - Italy. Ph: +390116704406; Fax: +390116703895. E-mail: \\ fabio.montobbio@unito.it.
}

${ }^{\varnothing}$ OECD, Structural Analysis and Comptitiveness Unit, OECD Development Centre (The opinions expressed in this paper are those of the author and do not necessarily reflect those of the Organization)

$\oint$ GREThA, UMR CNRS \& Université Bordeaux Montesquieu IV, Avenue Leon Duguit, F-33608 Pessac Cedex. E-mail: valerio.sterzi@u-bordeaux4.fr

${ }^{\oplus}$ KITES, Università Bocconi, Milan

\begin{abstract}
This paper studies international knowledge flows looking at (1) patent citations that track codified knowledge and (2) technological collaborations between inventors that gauge knowledge transmitted through face to face contacts. It uses a gravity model for 13 countries (Brazil, Russian Federation, India, China, South Africa and Mexico and USA, UK, Japan, Italy, Germany, France and Canada) using EPO data. Economic and institutional barriers exist to knowledge flows. Geographical distance has an indirect effect in particular through trade. Sharing a common legal origin and technological proximity favor the transfer of knowledge. When knowledge is tacit the economic (e.g. trade) and institutional determinants (e.g. legal origin) of knowledge flows have a much stronger impact. Finally there may be some adverse effects on knowledge flows generated by the reinforcement of IPRs in developing countries and in particular by the TRIPs agreements.
\end{abstract}

Jel Codes: O30, O10, O11

Keywords: Intellectual Property Rights, TRIPs, Knowledge flows, Emerging countries, Patent Citations, Inventors

Acknowledgments: We would like to thank Gianluca Tarasconi and Gemma Collotta for helpful research assistance. 


\section{Introduction}

International research collaborations and joint international patenting have been rising globally. Globalization and the diffusion of information and communication technologies increased the opportunities for collaborating, cooperating and sourcing knowledge from physically distant agents. In addition, the technological convergence and the emergence of new technological paradigms (such as biotechnology and nanotechnology) increased the need for carrying out joint research projects, which usually involve partners located in different countries. These trends multiply the opportunities for international knowledge flows through augmented possibilities of interaction between individuals and organizations. How those opportunities are translated into practice, and who is capturing the benefits depend, at the country level, on different factors, such as the accumulated capacities of the different agents, the prevailing specialization pattern, and also on the institutional management of innovation policy and intellectual property.

As innovation goes global, there is a rising demand for global knowledge governance. However, which mix of policies better supports the generation and diffusion of knowledge in global economies is still an open debate. Innovation policies per se are recently addressing the issue of international collaboration and international knowledge flows in their design phase; intellectual property protection is, probably, the domain in which policies have pioneered the extension of homogeneous standards across countries. The TRIPS agreement and the inclusion of IP chapters in bilateral trade and investment agreements (basically pursued by the US with developing and emerging economies) pushed for international harmonization of intellectual property rights thus shaping international regime for knowledge appropriation and circulation.

Starting from the 90s there has been a rising demand (especially pursued by the US) for regulations and legal mechanisms supporting intellectual property appropriability across countries. Actually, the issues related with IP management are frequently a bottleneck in the implementation of international research programs. It is quite obvious that asymmetries in intellectual property institutions and law challenge a smooth circulation of knowledge. Different legal legislations, differences in patent exceptions, patent subject matters and enforcement conditions, just to name a few, are considered to affect firms' decisions to locate firms in given countries, to influence the willingness to undertake collaborative research projects and to search for joint patent protection.

However, the prevailing legal framework is only one of the reasons that affect the decisions to collaborate for innovation with foreign partners. Usually, collaboration with foreign partners is manly determined by the need to access the capabilities (research or/and market based) and the knowledge (tacit or codified) embedded in the foreign partner. When the key motivation beyond collaboration is the 
uniqueness of the knowledge of the foreign counterpart and its value for the research or the business strategy of the partner, than asymmetries in IP regimes will tend to play a second order effect in agents' choices of collaborations. Nevertheless, international collaboration in applied research originates a demand for regulatory systems which should be suitable for incentivizing innovation the international level on fair basis.

In fact, countries differ in terms of technological specialization, accumulated capacities and institutions supporting the functioning of national innovation systems. The asymmetry between countries capabilities makes explicit that common rules and appropriability regimes impact different actors in different ways. The demand and supply of collaborations and knowledge flows for innovation is internationally asymmetric. And it is likely to be a more diffused phenomenon for (and between) advanced, already technologically advanced countries rather than for developing economies, which, at the aggregate level, basically lack the capabilities both to be suitable counterparts in research and to demand collaboration from foreign partners. However, for the latter the relevance of international collaboration in research and in inventive activity, although it is not determinant in share or allocated resources, it is extremely valuable for the transfer of tacit knowledge, routines and experience which derives from face-toface interaction and from the development of common shared practices ensuing from research collaboration.

In fact, while the impact of technology transfer on developing countries is considered, in the developmental literature, a necessary but not sufficient condition for modernization and catching up, if not matched by policies supporting the generation and strengthening of domestic capabilities, international knowledge flows are unanimously seen as positive and necessary elements for supporting catching up. Learning happens through cumulative processes of trial and errors. And collaboration in research is one of the channels through which information, knowledge and to some extent know-how flow between partners. Usually, joint research projects involve not only the exchange of technical information, but also the voluntary and involuntary transmission of know-how, procedures and routines, issues which make those collaborations, and the associated learning processes, of extreme relevance for catching up countries which are in the process of strengthening their capabilities.

Knowledge transmission from more advanced countries supports the catching up with the technological frontier; on the contrary, technological isolation slows down the development process and it is conducive to technological and economic divergence. The possibility of significant spillovers in the process of international knowledge diffusion has stimulated interest in technology transfer and has raised inevitably issues of intellectual property rights (IPRs) protection. However, developing countries encounter 
difficulties to "catch up" despite (and in some cases as a consequence of) the introduction of homogeneous and stronger IP regimes. In fact, the assumption that knowledge transfer can be easily accomplished is wrong. This is because thinking of technology in terms of blue prints and formulae is inadequate. A more advanced conceptualization of technology should include not only materials and knowledge codified in patents, blueprints and manuals but also know-how, routines and organizational capabilities, much of which is tacit in nature (Dosi, 1988).

Tacit knowledge is costly to transfer, and its transferability is limited by its embeddedness in individuals, teams and organizations. In this context particular attention is placed on the absorptive capacity, learning processes and the ability of the recipient country to evaluate and effectively use the transferred knowledge and technology. This is why research on knowledge diffusion through inter-personal links across countries has recently come to the fore. Possibly international knowledge spillovers are mainly driven not only by the effective transfer of codified knowledge, but also by interpersonal links and face-toface contacts across countries. International collaboration for developing countries plays a key role in accessing knowledge and good technology practices from abroad, and in speeding up the learning process.

Some evidence indicates that not only international collaboration between inventors is growing but also that international co-operation has a positive a significant effect on domestic innovative activity. In addition, developing countries seem to benefit significantly when domestic inventors collaborate with foreign inventors in developed countries (Montobbio and Sterzi, 2011).

TRIPS represent the biggest change in global IP regimes at the international level of the last two decades. The development literature has stressed, from many different points of view and on the basis of various argumentations, the (adverse) impact of the 1994 treaty on developing countries' technological catching up (Basheer, 2005; UNCTAD-ICTSD, 2005; Cimoli et al. 2009). However, while it is increasingly recognized that international flows of technological knowledge and collaboration in innovation affect importantly countries' ability to learn and innovate, few studies address the impact of TRIPS on international knowledge flows. This paper goes in this direction. It examines whether the upstream homogenization of IP regimes across countries, introduced by TRIPS in 1994, has supported international knowledge flows and international collaboration in research, as it was supposed to do in theory. Beyond the factors which have been already highlighted by the (controversial) literature on TRIPS and development (impact on FDI, on R\&D incentives, on prices, etc.) there could be something more "under the radar". The impact on the learning trajectory and of effective knowledge-and-know-how transfer from advanced to developing and emerging economies is an issue which should enter with plain rights into the analysis of the impact of a new IP legislation in catching up and developing economies. 
This paper studies the impact of the strengthening and homogenization of IPRs at the international level introduced by TRIPS on international knowledge flows, as measured by patent citations (which track the origin and direction of codified knowledge flows) and co-inventorship (as a proxy of technological collaboration that gauge knowledge that is transmitted through interpersonal and face to face contacts). The study is based on the international patent databases from the European Patent Office (EPO) and it covers 13 countries: the G7 (USA, UK, Japan, Italy, Germany, France and Canada) and a group of emerging economies, the BRICSM (Brazil, Russia, India, China, South Africa and Mexico). We use a modified version of a gravity equation to model bilateral technological cooperation and bilateral knowledge flows to test the impact of the strengthening of IPRs introduced by TRIPS.

In Section 1 we briefly analyze the evolution of international IPRs introduced by TRIPS and the impact of patenting on emerging and developing economies. Section 2 explains the two indicators used for measuring knowledge flows. Section 3 explores the available empirical evidence on the impact of TRIPS on knowledge flows. Section 4 presents the data and the empirical model and, finally, Section 5 discusses the results of the econometric exercise. Section 6 concludes.

\section{Harmonizing IP standards in a heterogeneous setting: an overview of the TRIPS}

IP regimes are regulatory frameworks embodied in evolving socio-economic systems; hence they are subject to change and evolution, on the basis of a combination of demand-push and technology push incentives. Since the 80 s advanced economies, especially the US entered into a "propatent" era introducing modifications in their national IP legislation which extended the patentable subject matter, enriching the scope for patentability and which induced, basically through the BahyDole Act, a transition to a more proprietary and commercialization-oriented science model, increasingly supporting the commercialization of university research (Dasgupta and David, 1994; Mazzoleni and Nelson, 1998; Mowery et al. 2004).

The Uruguay Round succeeded in setting most of those reforms as basic international standards for WTO members by the adoption of the TRIPS agreement. The adoption of the TRIPS agreement in 1994 marked a milestone in the big push towards homogeneous internaitonal minimum standards of IP protection. The progressive internationalization of IP protection went hand in hand with the increase in international trade and interactions between countries entailed by globalization, and was pulled by new interests arising from new technological paradigms and the rising articulation of global production processes. 
TRIPS establishes minimum standards of homogeneous protection among WTO members, introducing the two basic W'TO principles in IP management: the national treatment and the most favored nation treatment (TRIPS, articles 3 and 4). According to these principles, each WTO member is required to treat nationals of other member states at least as well as its own nationals, and to treat all other member states on an equivalent basis in relation to the protection of intellectual property.

In recent years developing countries expanded significantly the strength of their IPR legislations to comply with TRIPS requirement (Basheer, 2005). TRIPS requires that WTO member nations enact and enforce laws on copyrights, trademarks and patents to protect intellectual property. Rights expanded in many fields such as computer software, publications of various types, and pharmaceuticals. Besides the special and differential treatment (SDT) provisions which confer specific rights to LDC (Least Developed Countries) and a series of flexibilities, the Agreement put the reform and strengthening of IP in the innovation policy agenda of developing and emerging economies.

The basic rationale for the international harmonization and reinforcement of IPRs is based on three arguments. (1) Stronger IPRs would support technology transfer by reducing the risks to establish multinational corporations operations in developing countries (2) would create more incentives to sell goods in these markets, (3) would enhance international knowledge transfer through the development of markets for technologies. Arguments against the TRIPS policy emphasize the possibility of important welfare losses due to market power pricing, the costs of closing down infringing activities, higher imitation costs and other risks related to patenting indigenous knowledge, enforcement problems and the adverse impact on the trajectory of technological learning and catching up, as well as the mismatch between IP policies, innovation policy and industrial policy (Cimoli and Primi, 2008; Cimoli et al. 2009).

After the introduction of TRIPS, many scholars and polcy analysts studyied and assessed the impact of the agreement on developing countries. Various papers offered different measures of the effect of the TRIPS on trade, FDIs and innovation, as well as access to drugs. Generally, this literature suggests that the extension of patent protections under TRIPS has nuanced effects that varied by product category, country, and development level.

For example, McCalman (2001) estimated that the benefits from the harmonization of patent are concentrated mainly in the US. Kanwar and Evenson (2003) found evidence that IP rights spurred innovation (or at least investment in research and development) in a sample of 29 countries from 19811995. Allred and Park (2007) studied innovative activity in a panel of countries and find that there is no evident relationship between IPRs, R\&D investment and patenting activity in developing countries. Qian (2007 and 2008) show no statistically significant relationship between national pharmaceutical-patent 
protection and innovation or FDI establishments. The author shows, however, that the interactions of national patent-law implementation with development level, educational attainment, and economic freedom, respectively, are shown to have a positive relationship with domestic R\&D expenditures and domestic pharmaceutical-patent awards in the United States after national patent implementation. Coriat et al. (2006) show the adverse impact of TRIPS on access to drugs and health-care strategies in developing countries. Recent evidence about the impact of the TRIPs in the pharmaceutical sectors on investments and trade can be also found in Kyle and McGahan (2009) and Delgado et al. (2011). Overall this evidence suggests that the indirect link between reinforced IPRs and increased international knowledge flows should not be very strong.

Actually, patenting has intensified in the last decades. Year after year, patent offices receive a growing number of applications, and they are granting more patents, although this exponential growth showed signs of decline in the last 4-5 years. The increase in patenting activity is occurring globally. The leading economies in terms of technological and industrial capabilities still are major players; however, activity has also intensified in emerging economies and developing countries, paving the way for a reconfiguration of the traditional knowledge club. The North-South asymmetry in the dynamics of patenting activities corresponds to the North-South asymmetry in technological intensity of production structures and specialization patterns. That is, countries' participation in world patenting depends on the dynamics of their production structures and their processes of structural change. Developing countries spend few financial resources on $\mathrm{R} \& \mathrm{D}$, as they are in general specialized in low-knowledge intensive activities, especially natural resources and labor-intensive industries, and their domestic innovation efforts are basically adaptive in nature and rarely encompass inventions and scientific discoveries. Consequently their patenting activity is scarce. In contrast, industrialized countries are more specialized in knowledgeand technology-intensive sectors and they invest more resources in R\&D; it therefore comes as no surprise that they are also leaders in the number of patents applied for and granted (Cimoli et al. 2005; Montobbio, 2008).

If patenting activity is in general scant, we are aware that international patenting is a tiny portion of the innovative activity of emerging economies, not to mention developing countries. However we are not interested in the "magnitude" per se of the phenomenon, but on its implications on learning and knowledge transfer to domestic agents, in a cumulative process of catching up. Besides the "number of agents involved" the phenomena matters for its dynamic cumulative evolution. If knowledge flows from advanced to emerging countries represent one of the ways for learning and acquiring practice through direct collaboration, it is relevant to assess the impact of TRIPS not only on FDI or domestic innovation 
efforts, but on knowledge flows and joint collaborations in order to assess the impact on ongoing collaborations and contacts. In the data session, therefore, we give a precise quantitative assessment of the size of the phenomenon we are studying (see also Montobbio, 2008 for a broader discussion on international patenting in developing countries).

\section{Measuring International Knowledge Flows: Patent Citations and Co-inventorship.}

The economic literature has emphasized two ways of empirically tracking knowledge flows: patent citations and co-inventorship. This paper, in line with the literature, estimates the impact of IPRs reinforcement on both types of knowledge flows, which account for different types of knowledge flows and interactions between agents. Patent citations measure the transfer of codified and published knowledge. Collaboration via co-inventorship, i.e number of patents co-signed by inventors living in different countries, is a proxy of knowledge flows generated by interpersonal and social links deriving from joint collaboration. Patent citations measure flows of knowledge acquired by direct reading and comprehension of written and available documents, while co-inventor-ship can be used to track the transfer of non-codified knowledge (e.g. technical know-how, non-standardized production procedures etc.), which requires, at least periodically, face-to-face interactions. Collaboration via co-inventorship is particularly relevant since it is likely to have a great impact on technological learning and on making technology transfer effective.

There is a long tradition of studies that use patent citations to measure the value of the inventions and to map knowledge spillovers (Griliches, 1990). Albert et al. (1991) and Trajtenberg (1990) are among

the first authors who have shown that patents with a higher economic and technological importance are also highly cited. Since then a considerable number of paper has used patent citations to track knowledge flows and spillovers (Jaffe et al. 1993, Jaffe and Trajtenberg 1996, Jaffe and Trajtenberg, 1999; Maurseth and Verspagen, 2002; Malerba and Montobbio, 2003; Peri 2005; Bacchiocchi, Montobbio 2009 and 2010).

In this paper we use patent citations at the EPO. At the EPO, patent citations are included in the patent document mainly by the patent examiners in their examination report. Patent citations delimit the scope of the property right and point to the prior art that can possibly invalidate the patent. Citations have a legal value and they are considered a particularly reliable indicator. In this paper we assume that if patent A cites patent $B$, the inventors that signed patent $A$ know and use the knowledge embedded in $B$. In this way patent citations provide a possible knowledge trail that can be used to measure international knowledge flows. If, for example, a patent signed by a Brazilian inventor cites a patent signed by a Canadian inventor, it can be assumed that some knowledge created in the Canada is used in Brazil and, as a 
result, patent citations could track the direction of knowledge spillovers among the two inventors and the two countries ${ }^{1}$.

Knowledge flows via direct collaboration in research and face to face contacts are also important for innovation activities. The recognition of the relevance of personal interaction for knowledge transfer led the literature to measure knowledge flows through co-inventorship. Actually, knowledge and know-how embodied in individuals and firms circulates mainly through informal and non-codified face-to-face interactions and it involves different spheres, such as mobility of workers and researchers, participation to executive boards, effective participation in joint research programs etc. Co-inventorship can be used as a proxy of direct interaction, and hence transfer of experience, routines and knowledge between co-inventors.

Recently the literature has been using co-inventorship to to capture knowledge transfer between regions and countries (Breschi and Lissoni, 2001; Hoekman et al. 2009; Montobbio and Sterzi, 2012). Singh (2006) analyzes if and how interpersonal networks determine knowledge diffusion patterns in terms of geographic localization and intra-firm transfers using USPTO data since 1975. He finds that flows are stronger within firm and within regions than across them. He explores direct and indirect network ties between inventors, using past co-signed patents and finds that the social link between inventors is associated with a greater probability of knowledge flow (measured by patent citations), with the probability decreasing as the social 'distance' between inventors increases. Breschi and Lissoni (2009) show that inventors' mobility and the co-invention network are crucial determinants of knowledge diffusion.

The characteristics and the density of the community of inventors and the networks arising among them play a relevant role in the innovative process. Research collaborations create social networks which can foster mutual learning. Actually, joint research efforts and collaborations create opportunities for learning which go beyond the exchange of formalized and codified information and knowledge. Participation or exclusion from given research networks not only affect the innovative performance of the country, the region, the firm or the individual in question, it also affect the set of possibilities for learning routines and practices.

Besides the growing and cumulative efforts, measuring knowledge flows is certainly something that escapes the logic of a Cartesian analysis; however, using both patent citations and co-inventorships allows us to grasp, at least tentatively, the two main dimensions of knowledge flows: the codified and the tacit one.

\footnotetext{
1 Jaffe et al. (2000) tested this conjecture using USPTO patents and surveyed approx 380 citing and cited inventors. Results suggest that "communication between inventors is reasonably important, and that patent citations do provide an indication of communication, albeit one that also carries a fair amount of noise” (p. 215).
} 


\section{Does Patent Strength Facilitate International Knowledge Flows?}

This paper studies the determinants of these two different types of knowledge flows using a gravity model. In particular we ask whether strengthening IPRs increases knowledge flows between advanced and emerging economies. We consider bilateral knowledge flows between G7 and BRICSM countries and assume that they depend upon some joint characteristics of the two countries. Following the literature we study whether variables such as the economic size and innovative activities of the two countries, their geographical distance, the presence of common cultural roots, the level of foreign direct investment and bilateral trade, have an impact on knowledge flows. However, in particular we test how the adoption of TRIPS and the consequent increase in IP protection affects knowledge flows via patent citations and via coinventorship.

Standard economic analysis suggests that stronger IPRs increase the incentives of foreign companies to invest in knowledge related activities and also create more incentives to innovate for domestic companies. Moreover the (indirect) link between IPRs and knowledge flows passes through the level and composition of innovative activities. The general intuition is that an exogenous change in IP legislation in developing countries could raise the innovativeness of domestic companies and increase their economic openness, via FDIs, imports and joint ventures. Increased R\&D of domestic companies and openness could generate an increased level of international technological cooperation. Generally the strength of IPRs in a developing country should reassure companies willing to invest and develop technologies in these countries and, indirectly, be conducive to increased level of domestic technological activity and technological collaborations. Moreover new harmonized legislation and stricter enforcement generate greater incentives to disclose technological knowledge. Likewise, as long as stronger IPRs stimulate trade, FDI and international joint ventures this may improve both the probability of direct international collaborations between inventors and the probability of international patent citations (Park and Lippoldt, 2008).

However it has also been suggested that increased patent protection could harm innovative activities in developing countries. Part of the explanation comes from the discussion on the possible different strategies that multinational companies may adopt. As long as MNCs use patents to prevent the use or import of a specific technology this could harm domestic production and innovation. Moreover with stronger IPRs and stricter enforcement we can expect less international knowledge flows through imitation and adoption and the closing down infringing activities. Worries have also been expressed that stronger IPRs generate higher cost of access to imported technologies and difficulties in accessing basic 
scientific knowledge (McCalman, 2001; Grossman and Lai, 2004; Lai, 2008; Lerner 2000, Thompson and Rushing 1996; Mazzoleni and Nelson 1998).

If stronger IPRs end up hindering the research activity of developing countries in particular (maybe high tech) sectors and changing the structure and composition of their innovative activities we can expect a decline in the use of foreign technology in some fields and less international technological collaboration. Moreover strong domestic IPRs makes the local market more contendible and this may have an adverse effect on the domestic market structure, through mergers or acquisitions, and hence lead to a greater market concentration (Lesser, 1998), ultimately leading to the erosion of the local technical base.

Take now separately into account the effects on IPRs reinforcement on the two types of knowledge flows we consider in this paper. With respect to patent citations, we expect a positive impact of IP reinforcement on patent citations as long as this increases the use of foreign technology in the domestic technological activity of the developing countries. IP reinforcements may increase directly the use of technology facilitating the construction of domestic technological capabilities not only through higher incentives for domestic firms to perform R\&D but also through technology markets, licenses, technology outsourcing and contracts, enhancing also the overall capacity to absorb foreign knowledge. In parallel, there is a indirect effect through for example FDI and imports. At the same time stronger patent protection may hinder the use of foreign technology in particular for the potentially infringing innovative activities. In this case we should observe a decrease in patent citations. Moreover strengthening IPRs may also make more competitive the domestic market reducing the incentive to disclose knowledge and ideas (i.e. the opportunity cost of revealing information is higher). Potential limitations on the free use of foreign technology could lead to abandon innovative activities that eventually could have turned into an international patent application.

Moreover the use of foreign technology depend directly on the level of international technological collaboration. So we can consider the second type of knowledge flows measured by co-signed international patents and discuss how stronger IP may increase or decrease the incentives of companies in advanced countries to undertake international technological cooperation with companies in developing countries. In principle IPRs should reduce the costs of contracting because they generate a clearer definitions of the technologies and higher certainty about the enforceability of contracts. As a result of a reinforcement of IPRs, we should therefore observe more trade, FDIs and more R\&D collaborations between developed and developing countries.

We note also that - when it comes to international technological collaboration - different channels of technology transfer may be used. Companies and research laboratories in order to make profits out of 
their discoveries may pursuit different innovative and collaborative strategies. These different innovative strategies keep into account not only the strength of IP but also a lot of other variables like market size, the degree of appropriability, the intensity of the competition, the type of knowledge base, power relationships and the degree of asymmetry in the technological capabilities. Some evidence shows that substantial technological collaboration takes place also when strong IPRs are not enforced (e.g. Lanjouw, 1998 and Cockburn and Lanjouw, 2001). In this context it is not obvious how an IP reform that generate stronger patents and greater enforceability in developing countries could affect international technological collaboration. Consider the following example.

Let's assume that there are two countries (North and South). The North has stronger IPRs than the South. Assume also that there are two companies (A) and (B) with different level of technological capabilities. Company A is technologically more sophisticated and operates in the North and company B operates in the South. Company A discovers a new plant variety with new characteristics (e.g. in terms of therapeutic properties, resistance to specific pathogens or taste). Company B has a lab making research in the same field that could be a competitor and, at the same time, could adapt the plant variety to the local environment to set up for example production facilities. Company A may have an incentive to collaborate with company B not only for local production but also for international markets, if the product can be exported and the main destination markets are in the North. This leads to joint research, knowledge transfer and, eventually, company A could decide to file together with company B a patent in the destination markets.

How is this situation affected by modifications in the patent legislation in the South? May the international patent harmonization - and the resulting strengthening of IP for less developed countries reduce the incentive for company A to cooperate with company B ? In principle, with stronger IPRs, markets guarantee that company B does not misappropriate the technology of company A. This could generate a greater level of technological cooperation and technology transfer. However considering specific characteristics of technologies, markets and companies may lead to a less optimistic view.

(1) Company A could not want to share its tacit knowledge with a potential competitor: strengthening of IP makes the local market appealing and potentially profitable. Interpersonal links and face-toface cooperation involve a substantial transfer of knowledge. Not only knowledge that can be codified but also tacit knowledge.

(2) Strong IPRs and the creation of a market for technology may increase the incentive to license and decrease the incentives to undertake technological cooperation. With a weak patent legislation 
company A could find more profitable the cooperative solution (possibly with a fee or an access price), conversely with a strong patent legislation company A can always force company B to buy a license on its technology.

(3) Patents may involve substantial litigation and transaction costs. Company A could not want to cooperate with company B simply because it does not want to spend time and resources to negotiate complex licensing agreement.

(4) Company A may wish to access directly the market in the South that thank to IP reform is now more profitable. In many cases to cooperate technologically with a local company can provide increased appropriability because the local company can have important complementary assets, in particular the ability to adapt products to local needs and distribute them. Patent reform may change the appropriabilty strategy of foreign companies that can use stronger IP and stricter enforceability (instead of technological cooperation) to make profits out of their new products and processes.

\section{Data and Methodology}

Our patent data come from the EP - KITES data set, which contains complete information on all patent applications to the European Patent Office (EPO). In particular we use all patent applications from 13 countries from 1990 to 2004². We consider six developing countries: Brazil, Russian Federation, India, China, South Africa and Mexico (BRICSM) and 7 advanced countries (G7): Canada, France, Germany, Italy, Japan, UK and $\mathrm{US}^{3}$. Patents are assigned to countries using the addresses of the inventors and, in particular, are assigned to a specific country $i$ if there is at least one inventor resident in country $i$.

Our analysis focuses in particular upon international technological collaborations and knowledge flows between developing and developed countries:

(1) We observe an international technological collaboration between country A and country B when a patent is co-signed by at least one inventor resident in country $\mathrm{A}$ and at least one inventor resident in country $\mathrm{B}^{4}$. A possible noise in the data can be generated by individual inventors that work abroad but keep on declaring the address of the home country (e.g. Montobbio and Sterzi, 2012 for a discussion). We control for this by excluding those patents where the number of domestic inventors is less than $20 \%$ of the total number of inventors in the team. For example if we observe a patent with 6 US inventors and one Brazilian inventor we could argue that this is not an international collaboration between Brazil and the US

${ }^{2}$ In case of Russian Federation the panel goes from 1995 to 2004 due to missing information on IPR index till 1995 (Park, 2008).

3 The sample for the BRICSM countries is composed by 15035 patent applications, which have been signed by 30090 inventors.

${ }^{4}$ If a patents is signed by three inventors from three different countries in our sample, we consider all three bilateral relations. 
but rather that there is a Brazilian inventor working in a US institution. Table A1 in the Appendix shows that the majority of collaborative patents have a share of domestic inventors which is higher or equal to $20 \%$. On average this share ranges between 70\% for Brazil and 91\% for Russia.

(2) The second dependent variable we use is the number of bilateral patent citations. In particular we consider the yearly number of bilateral backward citations in patents signed by at least one inventor resident in the BRICSM to one of the G7 country.

The inventors' address is a more precise information than the applicant address. In dealing with developing countries, the applicant address may not contain the relevant information regarding the place where the innovative effort takes place. In many cases applicants are multinational corporations and in patent applications use the legal address of the headquarters even if the patent is the result of a collaborative effort with a foreign laboratory. Moreover in order to study technological collaborations it is much more appropriate to look at the inventor level, first because there are much more international collaborations if we look at international teams of inventors (with respects to patents that are co-applied by institutions in different countries) and secondly it is at the individual level that the real knowledge exchange takes place. To further justify this choice we show in the Appendix in Table A2 that the number international co-applications between a BRICSM country and a G7 country in the period 1997-2004 ranges between 19 in Mexico and 164 in China. Note that on average more than one third of these collaborations involve simply two individuals and that more than 10\% involve a university in the BRICSM countries.

\subsection{International knowledge flows in the BRICSM. A descriptive analysis}

Table 1 and Table 2 show the total number of patents per country per year and the share of patents with at least a foreign inventor (resident in the G7 countries), respectively for BRICSM and the advanced countries. It shows that BRICSM countries have a substantial share of international patents which are coinvented with the $G 7$ countries, at the same time the same percentage is very small for the G7 countries. While on average for the BRICSM the share of international collaborations range between 15\% and 60\% (higher for Mexico and smaller for South Africa) for the G7 countries the same share ranges between $0.2 \%$ and 4\% (higher for Canada and smaller for Japan). It is also important that this share is increasing in all the 7 advanced countries while no clear patterns emerge from the BRICSM. The share of international collaborative patents seems to decline in China and India indicating a growing importance of domestic technological activity in these two countries. At the same time it displays a positive trend in Brazil, Mexico and Russia with a peak in the mid-nineties and then either the trend remains flat or declines. 
Table 3 shows that total number of backward EPO citations of patents invented in the BRICSM countries. Only a minority represents citations that remain within the national borders (domestic citations). This is especially true for Mexico and China where only 2.7\% and 3.1\% are citations to domestic patents in 2004. Table 4 shows the average number of domestic inventors per patent in the BRICSM. Again it is important to note the high share of foreign inventors in Mexico, the growing importance of domestic inventors in China and India while the opposite occurs in Russia.

Table 5 shows the geographical reach of the BRICSM patents and Table 6 breaks down the BRICSM backward citations by countries of destination. Table 5 shows the number of patents with only national inventors, with at least an inventor from other BRICSM countries, the US, the EU (four countries) and Japan. If we consider two sub-periods, before and after 1996, Table 5 shows that the share of patents that have at least one inventor from the US tends to decrease for China, India and Mexico. The share of collaborative patents with the EU4 tends to decrease for all countries with the exception of Mexico and Russia.

Table 6 displays the number of backward citations by destination country (and shares) before and after 1996. No major structural change occurs in the period observed. There is a slight increase in citations that stay within the same country, but the share of these citations remain very low with the exception of South Africa in recent years. Table 6 also shows that geographical distance may play a role since China, India and Russian Federation are more likely to cite Japanese patents than Latin American countries. Interestingly, Mexico is closer to the United States, while Brazil more to the Europe: in the period 97-2003 $40 \%$ of the citations of Mexican patents go to the US and 32\% go to EU4 patents; while for Brazil we have the reversed picture with $39 \%$ of citations going to the EU4 and 30\% of their citations going to US patents.

Finally, Figure 1 and Figure 2 compare the technological composition of the collaborative patents with the one of the overall patenting activity in the BRICSM. Figure 1 shows that the BRICSM have different degrees and type of technological specializations. India and China have a higher degree of specialization: China in Electrical Engineering and India in Chemicals and Pharma. The other countries display a more uniform distribution across sectors with Brazil increasing substantially its technological activity in Pharmaceuticals. Interestingly, Figure 2, by showing the technological distribution of collaborative patents, indicates that for all countries at least half of the collaborative patents are concentrated in the fields of Chemical and Pharmaceuticals. This occurs also for those countries, like China, Russia, South Africa and Brazil, that do not display an overall specialization in these fields. 


\subsection{The Econometric model}

We estimate the impact of the IPRs strength and the TRIPS agreement on the international technological collaborations and on patent citations using a gravity model (Peri, 2005; Picci, 2008; Montobbio and Sterzi, 2012). Gravity models have been widely used in explaining trade flows. Disdier and Head (2008) show that the negative impact of distance on trade flows began to rise after the 1950s and remains high. Taking into account in their meta-analysis of approximately 1400 distance effects estimated in 103 different econometric papers, they show that the mean bilateral trade flow elasticity to distance is equal to 0.9 and challenge significantly the idea that with globalization distance is becoming less relevant.

Peri (2005) analyses knowledge flows across region in a gravity framework using patent citations. He finds that knowledge flows go much farther than trade flow even if knowledge flows remain highly localized. Guellec and van Pottelsberghe de la Potterie (2001) studies technological internationalization of the OECD countries and show that small and low tech countries are more open. They also find that technological collaboration depends upon technological proximity and the presence of both a common language and a common border. Finally, Picci (2008) studies international collaboration using co-inventors and co-applicants of a set of patent applications at the European national patent offices and at the EPO and studies the increased level of technological collaborations of the European countries. He finds that distance, common language and common borders explain a substantial part of the variation in bilateral collaborations.

In this vein this paper estimates the impact of IPRs reinforcement on different types of knowledge flows in the BRICSM countries using a gravity model. We follow a standard empirical implementation (e.g. Disdier and Head, 2008) for the expected value of $\mathrm{x}_{\mathrm{ij}, \mathrm{t}}$, that is, in our case, (1) the number of collaborations, where the number of domestic inventor is at least $20 \%$ of the total number of inventors, between developing country $i$ and developed country $j$ at time $t$ or, alternatively, (2) the yearly number of bilateral backward citations in patents signed by at least an inventor resident in country $i$ and citing a country $j$ at time $t$. The gravity equation can be represented in the following equation:

$\mathrm{E}\left[\mathrm{x}_{\mathrm{ijt}}\right]=\mathrm{A}_{\mathrm{it}}^{\alpha} \mathrm{A}_{\mathrm{jt}}^{\beta} \mathrm{D}_{\mathrm{ij}}^{\theta} \exp \left(\lambda \mathrm{ORIG}_{\mathrm{ij}}+\delta \mathrm{T}_{\mathrm{ij}}\right) \operatorname{IMP}_{\mathrm{ijt}}{ }^{v 1} \mathrm{FDI}_{\mathrm{it}}{ }^{v 2} \mathrm{IPR}_{\mathrm{it}}^{\gamma} \mathrm{e}^{\tau_{\mathrm{t}}}$

In this equation $\mathrm{A}^{\alpha}{ }_{\mathrm{it}}$ and $\mathrm{A}^{\beta}{ }_{\mathrm{jt}}$ measure specific characteristics of country $i$ and $j, \mathrm{D}_{\mathrm{ij}}$ is the geographical distance (DISTANCE ${ }_{i j}$ ) between them, where $\theta$ is the "distance effect" and represents the 
(negative) elasticity of bilateral patent citations or technological collaborations with respect to geographical distance.

The main variable under scrutiny is the general strength of the domestic intellectual system $\left(\operatorname{IPR}_{\mathrm{it}}\right)$. This variable is the Ginarte and Park index (Ginarte and Park, 1997; Park and Wagh, 2002; Park, 2008). This index ranges from zero to five and its value is the un-weighted sum of five sub-indexes that range from 0 to 1: (1) extent of coverage (subject matter and types of invention), (2) membership in international treaties, (3) duration of protection, (4) absence of restrictions on rights (e.g. degree of exclusivity), and, finally, (5) statutory enforcement provisions (e.g. preliminary injunctions). Secondly, in order to capture the TRIPS effect in the emerging countries we rely upon a treatment variable TRIPS $_{t}$ which is equal to one if $t \geq 1996$ and zero elsewhere., and we test whether it has a positive impact on the bilateral technological collaborations and backward citations between country $i$ and country $j$. For what concern the other variables, in the Appendix we provide a description of the datasets used (Table A3).

In particular in our empirical application $A_{i t}$ and $A_{j \mathrm{t}}$ are the constant price gdp $\left(\mathrm{GDP}_{i t}\right.$ and $\mathrm{GDP}_{i t}$ respectively for emerging and advanced country) and the total number of patent applications respectively of country $i$ and country $j$, at time $t\left(\mathrm{PATENTS}_{i t}\right.$ and PATENTS $\left.i t\right)$. Moreover we control for some further specific characteristics of developing countries $i$. We also expect technological collaborations to be related to the inflow of foreign direct investments $\left(\mathrm{FDI}_{\mathrm{it}}\right)$. Finally we augment the gravity model by including bilateral imports $\left(\mathrm{IMP}_{\mathrm{ijj}}\right)$ which represents the value of country $I$ import from country $j$.

$\mathrm{T}$ represents the technological proximity $\left(\mathrm{TP}_{\mathrm{ijt}}\right)$ between emerging and advanced countries. It is measured by the uncentered correlation of the two countries' distribution vectors of patents across 30 technological classes (OST, 2004) at time $t\left(\mathrm{P}_{\mathrm{i}}\right.$ and $\left.\mathrm{P}_{\mathrm{j}}\right)$, as follows: $\mathrm{TP}_{\mathrm{ij}}=\mathrm{P}_{\mathrm{i}} \mathrm{P}^{\prime}{ }_{\mathrm{j}} /\left[\left(\mathrm{P}_{\mathrm{i}} \mathrm{P}_{\mathrm{j}}{ }_{\mathrm{j}}\right)\left(\mathrm{P}_{\mathrm{j}} \mathrm{P}_{\mathrm{j}}\right)\right]^{1 / 2}$. This indicator typically ranges between 0 and 1 for all other pairs of countries. It is equal to one for the pairs of countries with identical distribution of technological activities; it is equal to zero if the distributions are orthogonal (Jaffe, 1988). Finally a dummy indicating a common legal origin (ORIG $\mathrm{ij}_{\mathrm{ij}}$ ) which is equal to one if $i$ and $j$ have a common legal origin (La Porta et al. ,1999).

Our dependent variables are non-negative integers and challenge the use of linear regression models such as OLS. Moreover, since their distribution is highly skewed and the frequency of zeros is quite important (30\%), we rely upon the PPML estimator, as suggested by Santos Silva and Tenreyro (2006), with the classical Huber and White sandwich estimator of variance (Huber, 1967, White, 1980). Finally, since observations in pairs of countries are likely to be dependent across years, robust standard errors are clustered to control for error correlation in the panel (Cameron and Golotvina, 2005). All the regressions contain a full set of time dummies $\left(\tau_{t}\right)$ to control for time varying un-observables that are common across 
countries or, alternatively, a non-linear trend. Moreover we include unobserved individual time constant effect specific to country $i$ and country $j$ (in the Tables reported as POISSON estimates). Table 5 shows the regression variables statistics.

\section{Results}

In this section we present the estimates of the gravity models. In column (1)-(3) we run simple POISSON regressions with individual time constant effects specific to emerging and advanced country; in column (4) and (5) we run fixed effects POISSON regressions which include fixed effects relative to each specific pair of countries. Moreover all models contain a full set of time dummies which capture any time shock that is common to all bilateral relations.

First we estimate the effect of our selected determinants on knowledge flows measured by patterns of co-inventorship (Table 8). Secondly we ask how the same determinants affect the transfer of knowledge captured by patent citations (Table 9). A group of results are common in the two sets of regressions. The estimates show that the gravity model is asymmetric because the masses measured by patenting activity and GDP have different effect according to emerging and advanced country. In particular patenting activity has a positive and significant effect only in the case of patent applications by emerging country (ln PATENTS $_{\text {it) }}$.

Secondly, looking at column (1) of Table 8 and 9 it is possible to see that DISTANCE $\mathrm{ij}_{\mathrm{ij}}$ is significantly negative. This could suggest that communication and transportation costs might play a significant role in determining the geographical scope of knowledge flows. Note that the estimated effect of DISTANCE is larger for technological collaborations (-0.39 vs. -0.14). However it is important to underline that, for both types of knowledge flows, what we observe in column (1) is not only a direct effect of geographical distance on knowledge flows but also an indirect effect through trade.

International trade theory has shown that geographical distance significantly affects trade flows and so, if we omit trade in the model, we capture both effects. However, the estimated distance elasticity is no more significant once we include the other covariates in the regressions (columns (2) and (3)). In particular, the inclusion of bilateral trade relationships overturns the effects of geographical distance. In sum columns (2) and (3) in both Tables 8 and 9 show the direct distance elasticity on knowledge flows and show that controlling for trade (and other broader set of variables) it is no more statistically different from zero.

The elasticity of bilateral import is positive and significant in POISSON regression in line with the literature on knowledge spillover (Coe and Helpman, 1995), and the effect is stronger for technological 
collaborations. In Table 8 and 9 in the POISSON Fixed Effect models the impact of trade is not statistically significant. FDIs have not a significant effect or have a weakly negative one in the model with patent citations.

Finally if geographical distance is no more significant once controlling for trade, other forms of distances - such as having a common legal origin $\left(\mathrm{ORIG}_{\mathrm{ij}}\right)$ and similarity in the technological distribution of the inventive activity $\left(\mathrm{TP}_{\mathrm{ijt}}\right)$ - have still a significant effect. In particular, having a common legal origin increases the expected number of collaborations by a factor of 1.60, holding all other variables constant. The effect is positive also for patent citations. Conversely technological proximity is positive and significant only for technological collaborations. $\mathrm{TP}_{i j t}$ is not positively related to backward citations in POISSON models, and in addition, controlling for unobserved pair characteristics through fixed effect models (columns 4 and 5), it appears negative and significant.

Our results do not highlight any positive effect of strengthening IPRs on knowledge flows (technological collaborations and patent citations) neither in POISSON models nor in POISSON FE models. For the BRICSM countries, variations in the IPR variable can be directly related to the compliance to the TRIPS agreements in 1996. To control for this possibility we introduce also the variable TRIPS (a $^{2}$ dummy variable that is equal to 1 for the year 1996-2004 and zero otherwise) in order to control for that portion of variation that can be attributed to this agreement. Table 8 shows that the estimated coefficient of the TRIPS agreement on international technological collaborations is negative but still not significantly different from zero (column (3) and (5)). Altogether these results do not provide any signal of a positive effect of IPRs reinforcement on knowledge flows captured by international patenting collaborations.

Table 9 shows that in the case of patent citations strengthening IPRs, differently from the international collaborations case, has a negative and significant impact on the international knowledge flows. In particular, the TRIPS variable has a significant and negative effect on the number of citations, also controlling for the IPRs index. According to estimates in column (3) and (5), after the 1996 Trips agreement the expected number of backward citations is decreased by a factor of 0.03 , holding all other variables constant. In sum our evidence using EPO patents suggests that IPRs has not a strong effect on knowledge flows. In particular when we measure them using patent citations, which we assume to track codified knowledge, the effect is negative and emerging countries seem to be less able to use the knowledge produced in the advanced countries. When we measure knowledge flows using co-inventorship, which we assume to be a proxy knowledge that is transmitted through interpersonal and face to face contacts, the effect of IPRs is not statistically significant. 


\section{Conclusion}

As innovation goes global, there is a rising demand for global knowledge governance. This issue is at the center of the political debate in advanced, as well as in emerging and developing economies. However, which mix of policies better supports the generation and diffusion of knowledge in global economies on a faire basis is still an open debate. Shortcuts are probably not the best policy options when innovation and the building of capacities and capabilities for innovation are at stake. And this is especially in the case of catching up and developing economies, which on the one hand, require targeted policies to support the generation of domestics capabilities, but which on the other hand, also require specific policies to support learning and contacts with more advanced counterparts to support their domestic efforts and to facilitate the transfer and the absorption of capabilities, routines, and practices, beyond traditional technology transfer.

Innovation is increasingly the result of the combination of knowledge, know-how, competences and techniques whose generation and diffusion occur usually involving international counterparts. Research and inventions with industrial applications will increasingly be a global phenomena. However, the possibility for catching up and developing economies of profiting from increased opportunities of collaboration cannot rely on market forces alone. A mix of policies is needed to support the generation of domestic capabilities and to support a virtuous integration to the global knowledge economies.

In developing countries access to foreign technologies, collaboration with foreign counterparts, both in the domestic country and abroad is a hot political issue. Scientific research increasingly involves international counterparts and mobility of researchers is on the rise. Collaborative links with foreign laboratories rely more on relational and capability proximity than on geographical distance. Also, multinationals are increasingly delocalizing $R \& D$ activities in host countries, spurring a debate on which are the conditions under which the local community of researchers and firms can learn by tapping into foreign collaborative networks.

Governments, for example in Brazil, in Mexico as well as in India, set up different types of incentives for their researchers to build close interpersonal collaboration with foreign researchers, and encourage local firms to collaborate with foreign subsidiaries to access foreign knowledge, or support delocalization of firms to learn from foreign practices in foreign markets. However, while those policies are managed under the innovation policy umbrella, there are other policies affecting international knowledge flows and learning by collaborating: mainly IP regulations. Perfect coordination in policy design is not realistic, not even in developed countries, but synchronization between policies is desirable. 
In this context our paper contributes in two ways. First of all we compare the economic and institutional determinants of two types of knowledge flows. The ones that flow disembodied and codified and the ones that, since technical knowledge is in many aspect specific and tacit, are transmitted through face to face contacts. We show the economic and institutional barriers that exist to these knowledge flows between advanced and emerging countries. We show that geographical distance (e.g. communications and transport costs) has an indirect effect on knowledge flows in particular through trade. We show that sharing a common legal origin and in some technological proximity may favor the transfer of knowledge. Our results show also that when knowledge is tacit the economic and institutional determinants of knowledge flows have a stronger impact. The impact of bilateral imports and sharing a common legal origin is two times larger in the case of international technological collaborations compared to patent citations.

Secondly we discuss the impact on knowledge diffusion of intellectual property reinforcement in emerging countries. Intellectual property regimes are, as all economic and legal institutions, context and time specific, and they are subject to change. In terms of evolution of intellectual property rights, if a lesson can be derived from history, it is that systems evolved as pulled by the production side. When, in a given country, the introduction of IP protection could bring about a pecuniary gain in a given sector or area, the system was adapted, or a negotiation initiated to grant the right of appropriation of the relative rent. In contrast, sectors, lobbies (and countries) attempted to block the introduction of IP protection in cases in which they were net importers of the product or service in question.

Our paper contributes to this policy debate with a warning flag. Our evidence suggests that there may be some adverse effects on knowledge flows generated by the reinforcement of IPRs in emerging economies and in particular by the TRIPs agreements. In particular our estimates tend to show that IPRs reinforcement has not a positive effect on both types knowledge flows between the BRICSM countries and the $G 7$ countries.

In terms of political economy, having a national strategy for scientific, industrial and technological development lays the foundations for strategically using IP for development. The strengthening and homogenization of IP could jeopardize some ongoing learning processes base con collaboration in catching up and emerging economies. However, the debate on intellectual property seems more oriented towards technology transfers and markets for knowledge rather than on a critical reflection of current norms. On the contrary, in advanced countries, there is a rising concern that current IP management could harm instead of supporting innovation. Probably there is a window of opportunity for twisting the debate 
and contextualizing IP management in a wider logic of knowledge circulation and appropriability. Whether the BRICSM will take the lead on this is an open question.

\section{References.}

Albert, M.B., Avery, D., Narin, F., and McAllister, P., (1991); "Direct Validation of Citation Counts as Indicators of Industrially Important Patents”. Research Policy, 20:251-259;

Allred, B. and W. Park, (2007), "Patent Rights and Innovative Activity: Evidence from National and Firmlevel Data," Journal of International Business Studies;

Bacchiocchi E. and Montobbio F. (2009), "Knowledge diffusion from university and public research. A comparison between Us, Japan, and Europe using patent citations", Journal of Technology Transfer, 34:169-181.

Bacchiocchi E., Montobbio F. (2010); International knowledge diffusion and home-bias effect. Do USPTO \& EPO patent citations tell the same story?. Scandinavian Journal of Economics. 112(3),pp. 441 470.

Basheer, S. (2005), India's tryst with TRIPS: the patents (amendment) Act 2005, The Indian Journal of Law and Technology, Volume 1, 2005, 15-43

Breschi S. Lissoni F. (2001), "Knowledge Spillovers and Local Innovation System: A Critical Survey", Industrial and Corporate Change, 10(4): 975-1005;

Breschi S. Lissoni F. (2009), "Mobility of skilled workers and co-invention networks: an anatomy of localized knowledge flows", Journal of Economic Geography, 9(4): 439-468;

Cimoli, M., B. Coriat and A. Primi (2009), Intellectual property and industrial development: a critical assessment, in Cimoli, M., G. Dosi and J. E. Stiglitz, (2009), Industrial Policy and Development: the political economy of capabilities accumulation, Oxford University Press, chp. 19.

Cimoli, M. and A. Primi (2008), 'Technology and intellectual property a taxonomy of contemporary markets for knowledge and their implications for development' LEM Working Paper Series, 2008/06

Coriat, B., F. Orsi and C. d'Almeida (2006) TRIPS and the international public health controversies: issues and challenges, Industrial and Corporate Change 2006 15(6):1033-1062;

Dasgupta, P. and P. David (1994). 'Toward a New Economics of Science.' Research Policy 23 (5), pp. 487521.

Delgado, M., Kyle, M., McGahan, A.M. (2011) .The influence of intellectual property protection on the geography of trade in knowledge-intensive goods. Working Paper. 
Dosi, G. (1988), Sources, procedures and microeconomic effects of innovation, Journal of Economic Literature, 26, 1120-1171

Disdier, A. C. and Keith Head, 2008. "The Puzzling Persistence of the Distance Effect on Bilateral Trade," The Review of Economics and Statistics, MIT Press, vol. 90(1), pages 37-48, 09;

Fink, C. and P. Reichenmiller (2005), 'Tightening TRIPS: The Intellectual Property Provisions of Recent US Free Trade Agreements',World Bank Trade Note, no. 20, February 2005.

Griliches Z. (1990), "Patent Statistics as Economic Indicators: A Survey", Journal of Economic Literature, 18: 1661-1707;

Gene M. Grossman \& Edwin L.-C. Lai, 2004. "International Protection of Intellectual Property," American Economic Review, 94(5): 1635-165;

Hoekman, J., Frenken, K., and Van Oort, F. (2009) The geography of collaborative knowledge production in Europe, Annals of Regional Science 43, 721-738.

Jaffe, A.B., Trajtenberg M., and Henderson R., (1993), „Geographic Localization of Knowledge Spillovers as Evidenced by Patent Citations”, The Quarterly Journal of Economics, 108: 577-598;

Jaffe A.B., Trajtenberg M., (1996), "Flow of Knowledge from Universities and Federal Laboratories: Modelling the Flow of Patent Citations over Time and across Institutional and Geographic Boundaries", Proceedings of the National Academy of Sciences 93: 12671-12677;

Jaffe, A.B., M. Tratjenberg (1999). International Knowledge Flows: Evidence from Patent Citations. Economics of Innovation and New Technology, 8: 105-136;

Kanwar, S. and R. Evenson (2003), "Does Intellectual Property Protection Spur Technological Change?” Oxford Economic Papers 55, pp. 235-264;

Kyle MK, McGahan (2009); Investment in Pharmaceuticals before and after the Trips. NBER Working Paper 15468.

Laforgia F., Montobbio F., Orsenigo L. (2007); IPRs and Technological Development in Pharmaceuticals: Who is Patenting What in Brazil after the TRIPS?, in Netanel Neil (ed.) The Development Agenda: Global Intellectual Property and Developing Countries. Oxford University Press;

La Porta R., Lopez de Silanes F., and Shleifer A. (1998), "Law and Finance", Journal of Political Economy, 106(6): 1113-1155;

Lanjouw, J., (1998). The Introduction of Pharmaceutical Product Patents in India: Heartless Exploitation of the Poor and Suffering? NBER Working Paper 6366;

Lanjouw, J. O. and Iain Cockburn (2001) "New Pills for Poor People?: Empirical Evidence After GATT," World Development. Vol. 29, no. 2, pp. 265-89; 
Lesser, W. 1998. Intellectual Property Rights and Concentration in Agricultural Biotechnology. AgBioForum 1(2): 56-61;

Malerba F., Montobbio F. (2003); Exploring Factors Affecting International Technological Specialization: the Role of Knowledge Flows and the Structure of Innovative Activity, Journal of Evolutionary Economics, v. 13, n. 4: 411-434;

Maurseth B., Verspagen B., (2002), "Knowledge Spillovers in Europe: A Patent Citations Analysis". Scandinavian Journal of Economics: 104:4, 531;

Mazzoleni, Roberto \& Nelson, Richard R., 1998. "The benefits and costs of strong patent protection: a contribution to the current debate," Research Policy, 27(3): 273-284;

McCalman, P. (2001), "Reaping what you sow: an empirical analysis of international patent harmonization," Journal of International Economics, 55: 161-186;

Moncayo, A. (2006), 'Bilateralismo y multilateralismo en materia de patentes de invención: una interaccio'n compleja', background paper, Sistemas de Propiedad Intelectual y Gestio'n Tecnolo'gica en Economı́as Abiertas: Una Visión Estrate'gica para América Latina y el Caribe, Estudio OMPI CEPAL.

Montobbio F. (2008); Patenting Activity in Latin American and Caribbean Countries. In World Intellectual Property Organization (WIPO) - Economic Commission for Latin America and the Caribbean (ECLAC) - Study on Intellectual Property Management in Open Economies: A Strategic Vision for Latin America".

Montobbio F., Sterzi V. (2011); Inventing Together: Exploring the Nature of International Knowledge Spillovers in Latin America. Journal of Evolutionary Economics, 21: pp.53-89

Montobbio F., Sterzi V. (2012). The globalization of technology in emerging markets: a gravity model on the determinants of international patent collaborations. Working Paper No. 08/2012. Dipartimento di Economia "S. Cognetti de Martiis". University of Turin.

Mowery, D. C., R. R. Nelson, B. N. Sampat, and A. A. Ziedonies (2004), The Ivory Tower and Industrial Innovation: University Industry Technology Transfer before and after the Bayh Dole Act, California, Stanford University Press

OST (2004), "Indicateurs de sciences et de technologies", Rapport de l'Observatoire des Sciences et des Techniques, Paris: Economica;

Park, W.G., and J.C. Ginarte (1997), "Intellectual Property Rights and Economic Growth,” Contemporary Economic Policy, 51-61;

Park, W. G. and D. C. Lippoldt (2008), "Technology Transfer and the Economic Implications of the Strengthening of Intellectual Property Rights in Developing Countries", OECD Trade Policy Working Papers, No. 62, OECD Publishing. doi:10.1787/244764462745 ;

Park, W., (2008). International patent protection: 1960-2005. Research Policy, 37:761-766; 
Peri G. (2005), "Determinants of Knowledge Flows and Their Effect on Innovation", The Review of Economics and Statistics, 87(2): 308-322.

Picci L. (2008), “The Internationalization of Inventive Activity: A Gravity Model Using Patent Data”, Mimeo;

Qian, Y. (2007), Do National Patent Laws Stimulate Domestic Innovation in a Global Patenting Environment? A Cross-Country Analysis of Pharmaceutical Patent Protection, 1978-2002, Review of Economics and Statistics 89: 3;

Qian, Y. (2008) Are national patent laws the blossoming rains? Evidence from domestic innovation, technology Transfer and International Trade Post patent Implementations in the periods 1978 2002, in Netanel Neil (ed.) The Development Agenda: Global Intellectual Property and Developing Countries. Oxford University Press;

Singh J. (2005), "Collaborative networks as determinants of knowledge diffusion pattern", Management Science, 51:756-770.

Thompson, M.A., and F.W. Rushing (1996), "An Empirical Analysis of the Impact of Patent Protection on Economic Growth,” Journal of Economic Development, 21(2): 61-79;

Trajtenberg, M. (1990), "A Penny for Your Quotes: Patent Citations and the Value of Innovations". The RAND Journal of Economics, 21(1): 172-187;

UNCTAD-ICTSD (2005), Resource Book on TRIPS and Development, Cambridge University Press. 
TABLES AND FIGURES 
Table 1. Patents and collaborative patents (by inventors), BRICSM countries, EPO patents

\begin{tabular}{|c|c|c|c|c|c|c|c|c|c|c|c|c|c|c|c|c|c|c|}
\hline \multirow[b]{2}{*}{ year } & \multicolumn{3}{|c|}{ BRAZIL } & \multicolumn{3}{|c|}{$C H I N A$} & \multicolumn{3}{|c|}{$I N D I A$} & \multicolumn{3}{|c|}{ MEXICO } & \multicolumn{3}{|c|}{ RUSSLA } & \multicolumn{3}{|c|}{ SOUTH AFRICA } \\
\hline & $\begin{array}{c}\text { Tot } \\
\text { al }\end{array}$ & $\begin{array}{l}\text { Collabor } \\
\text { ative }\end{array}$ & $\%$ & Total & $\begin{array}{c}\text { Colla } \\
\text { borat } \\
\text { ive }\end{array}$ & $\%$ & Total & $\begin{array}{l}\text { Collab } \\
\text { orative }\end{array}$ & $\%$ & $\begin{array}{l}\text { To } \\
\text { tal }\end{array}$ & $\begin{array}{l}\text { Collabora } \\
\text { tive }\end{array}$ & $\%$ & $\begin{array}{l}\text { To } \\
\text { tal }\end{array}$ & $\begin{array}{c}\text { Collaborat } \\
\text { ive }\end{array}$ & $\%$ & $\begin{array}{l}\text { To } \\
\text { tal }\end{array}$ & $\begin{array}{l}\text { Collabora } \\
\text { tive }\end{array}$ & $\%$ \\
\hline 1990 & 51 & 10 & $20 \%$ & 36 & 9 & $25 \%$ & 34 & 17 & $50 \%$ & 18 & 5 & $28 \%$ & 72 & 4 & $6 \%$ & 63 & 8 & $13 \%$ \\
\hline 1991 & 35 & 9 & $26 \%$ & 38 & 13 & $34 \%$ & 22 & 10 & $45 \%$ & 14 & 2 & $14 \%$ & 90 & 13 & $14 \%$ & 71 & 8 & $11 \%$ \\
\hline 1992 & 58 & 16 & $28 \%$ & 45 & 18 & $40 \%$ & 31 & 13 & $42 \%$ & 16 & 7 & $44 \%$ & 143 & 29 & $20 \%$ & 126 & 12 & $10 \%$ \\
\hline 1993 & 60 & 14 & $23 \%$ & 45 & 26 & $58 \%$ & 44 & 26 & $59 \%$ & 25 & 16 & $64 \%$ & 148 & 39 & $26 \%$ & 108 & 18 & $17 \%$ \\
\hline 1994 & 45 & 12 & $27 \%$ & 54 & 18 & $33 \%$ & 34 & 21 & $62 \%$ & 22 & 14 & $64 \%$ & 173 & 56 & $32 \%$ & 84 & 9 & $11 \%$ \\
\hline 1995 & 77 & 34 & $44 \%$ & 74 & 31 & $42 \%$ & 45 & 20 & $44 \%$ & 35 & 17 & $49 \%$ & 169 & 53 & $31 \%$ & 92 & 20 & $22 \%$ \\
\hline 1996 & 69 & 24 & $35 \%$ & 93 & 36 & $39 \%$ & 74 & 32 & $43 \%$ & 30 & 11 & $37 \%$ & 216 & 70 & $32 \%$ & 94 & 15 & $16 \%$ \\
\hline 1997 & 109 & 26 & $24 \%$ & 133 & 55 & $41 \%$ & 83 & 25 & $30 \%$ & 58 & 22 & $38 \%$ & 213 & 74 & $35 \%$ & 152 & 19 & $13 \%$ \\
\hline 1998 & 115 & 66 & $57 \%$ & 153 & 49 & $32 \%$ & 147 & 53 & $36 \%$ & 47 & 24 & $51 \%$ & 255 & 87 & $34 \%$ & 163 & 26 & $16 \%$ \\
\hline 1999 & 142 & 31 & $22 \%$ & 250 & 67 & $27 \%$ & 183 & 72 & $39 \%$ & 56 & 26 & $46 \%$ & 279 & 105 & $38 \%$ & 154 & 24 & $16 \%$ \\
\hline 2000 & 137 & 36 & $26 \%$ & 406 & 136 & $33 \%$ & 224 & 69 & $31 \%$ & 42 & 22 & $52 \%$ & 287 & 100 & $35 \%$ & 165 & 37 & $22 \%$ \\
\hline 2001 & 171 & 51 & $30 \%$ & 509 & 128 & $25 \%$ & 321 & 77 & $24 \%$ & 59 & 27 & $46 \%$ & 301 & 101 & $34 \%$ & 132 & 22 & $17 \%$ \\
\hline 2002 & 153 & 33 & $22 \%$ & 692 & 166 & $24 \%$ & 499 & 109 & $22 \%$ & 67 & 31 & $46 \%$ & 238 & 87 & $37 \%$ & 144 & 18 & $13 \%$ \\
\hline 2003 & 201 & 46 & $23 \%$ & 1136 & 216 & $19 \%$ & 597 & 178 & $30 \%$ & 86 & 34 & $40 \%$ & 277 & 101 & $36 \%$ & 151 & 17 & $11 \%$ \\
\hline 2004 & 212 & 69 & $33 \%$ & 1256 & 243 & $19 \%$ & 591 & 186 & $31 \%$ & 70 & 34 & $49 \%$ & 280 & 93 & $33 \%$ & 149 & 27 & $18 \%$ \\
\hline TOTAL & 1635 & 477 & $29 \%$ & 4920 & 1211 & $25 \%$ & 2929 & 908 & $31 \%$ & 645 & 292 & $45 \%$ & 3141 & 1012 & $32 \%$ & 1848 & 280 & $15 \%$ \\
\hline
\end{tabular}


Table 2. Patents and collaborative patents (by inventors), G7 countries, EPO patents

\begin{tabular}{|c|c|c|c|c|c|c|c|c|c|c|c|c|c|c|c|c|c|c|c|c|c|}
\hline & \multicolumn{3}{|c|}{ USA } & \multicolumn{3}{|c|}{ JAPAN } & \multicolumn{3}{|c|}{ GERMANY } & \multicolumn{3}{|c|}{ UK } & \multicolumn{3}{|c|}{ ITALY } & \multicolumn{3}{|c|}{ CANADA } & \multicolumn{3}{|c|}{ FRANCE } \\
\hline & Total & Coll. & $\%$ & Total & Coll. & $\%$ & Total & Coll. & $\%$ & Total & Coll. & $\%$ & Total & Coll. & $\%$ & Total & Coll. & $\%$ & Total & Coll. & $\%$ \\
\hline 1990 & 124957 & 673 & $0.54 \%$ & 92078 & 271 & $0.29 \%$ & 82838 & 351 & $0.42 \%$ & 26404 & 319 & $1.21 \%$ & 16184 & 96 & $0.59 \%$ & 4263 & 109 & $2.56 \%$ & 35462 & 197 & $0.56 \%$ \\
\hline 1991 & 124516 & 788 & $0.63 \%$ & 83055 & 256 & $0.31 \%$ & 82103 & 409 & $0.50 \%$ & 26019 & 391 & $1.50 \%$ & 16660 & 98 & $0.59 \%$ & 4494 & 155 & $3.45 \%$ & 35819 & 241 & $0.67 \%$ \\
\hline 1992 & 127862 & 886 & $0.69 \%$ & 77581 & 271 & $0.35 \%$ & 83594 & 465 & $0.56 \%$ & 26019 & 414 & $1.59 \%$ & 15722 & 104 & $0.66 \%$ & 4879 & 172 & $3.53 \%$ & 33803 & 262 & $0.78 \%$ \\
\hline 1993 & 133539 & 945 & $0.71 \%$ & 79114 & 244 & $0.31 \%$ & 85470 & 430 & $0.50 \%$ & 26467 & 407 & $1.54 \%$ & 16415 & 108 & $0.66 \%$ & 5313 & 175 & $3.29 \%$ & 35231 & 325 & $0.92 \%$ \\
\hline 1994 & 142107 & 1120 & $0.79 \%$ & 78008 & 309 & $0.40 \%$ & 91469 & 544 & $0.59 \%$ & 27923 & 473 & $1.69 \%$ & 16954 & 128 & $0.75 \%$ & 5691 & 182 & $3.20 \%$ & 36596 & 316 & $0.86 \%$ \\
\hline 1995 & 158431 & 1262 & $0.80 \%$ & 89054 & 320 & $0.36 \%$ & 95578 & 615 & $0.64 \%$ & 29421 & 548 & $1.86 \%$ & 18109 & 154 & $0.85 \%$ & 6727 & 241 & $3.58 \%$ & 38038 & 386 & $1.01 \%$ \\
\hline 1996 & 168504 & 1470 & $0.87 \%$ & 101094 & 364 & $0.36 \%$ & 114513 & 816 & $0.71 \%$ & 32830 & 704 & $2.14 \%$ & 21217 & 208 & $0.98 \%$ & 7518 & 266 & $3.54 \%$ & 41916 & 554 & $1.32 \%$ \\
\hline 1997 & 188762 & 1922 & $1.02 \%$ & 108241 & 415 & $0.38 \%$ & 128639 & 1013 & $0.79 \%$ & 35791 & 814 & $2.27 \%$ & 23254 & 244 & $1.05 \%$ & 10059 & 383 & $3.81 \%$ & 47117 & 671 & $1.42 \%$ \\
\hline 1998 & 205604 & 2137 & $1.04 \%$ & 113918 & 502 & $0.44 \%$ & 144606 & 1255 & $0.87 \%$ & 39900 & 882 & $2.21 \%$ & 24605 & 254 & $1.03 \%$ & 11564 & 461 & $3.99 \%$ & 50925 & 747 & $1.47 \%$ \\
\hline 1999 & 221781 & 2486 & $1.12 \%$ & 131663 & 522 & $0.40 \%$ & 155169 & 1433 & $0.92 \%$ & 44933 & 1042 & $2.32 \%$ & 27265 & 273 & $1.00 \%$ & 13132 & 533 & $4.06 \%$ & 54481 & 845 & $1.55 \%$ \\
\hline 2000 & 227108 & 2784 & $1.23 \%$ & 151669 & 527 & $0.35 \%$ & 162890 & 1691 & $1.04 \%$ & 47110 & 1194 & $2.53 \%$ & 29519 & 357 & $1.21 \%$ & 13608 & 598 & $4.39 \%$ & 55678 & 983 & $1.77 \%$ \\
\hline 2001 & 220850 & 2597 & $1.18 \%$ & 138530 & 480 & $0.35 \%$ & 160356 & 1486 & $0.93 \%$ & 44170 & 1228 & $2.78 \%$ & 29239 & 316 & $1.08 \%$ & 14056 & 611 & $4.35 \%$ & 55636 & 988 & $1.78 \%$ \\
\hline 2002 & 228291 & 2569 & $1.13 \%$ & 140420 & 559 & $0.40 \%$ & 158872 & 1598 & $1.01 \%$ & 42819 & 1132 & $2.64 \%$ & 30618 & 341 & $1.11 \%$ & 14238 & 557 & $3.91 \%$ & 56182 & 1040 & $1.85 \%$ \\
\hline 2003 & 232176 & 2615 & $1.13 \%$ & 147798 & 500 & $0.34 \%$ & 160923 & 1633 & $1.01 \%$ & 42371 & 1067 & $2.52 \%$ & 31976 & 380 & $1.19 \%$ & 14623 & 584 & $3.99 \%$ & 60200 & 1091 & $1.81 \%$ \\
\hline 2004 & 233919 & 2759 & $1.18 \%$ & 153195 & 524 & $0.34 \%$ & 166208 & 1696 & $1.02 \%$ & 41566 & 1183 & $2.85 \%$ & 32599 & 390 & $1.20 \%$ & 16478 & 561 & $3.40 \%$ & 61922 & 1097 & $1.77 \%$ \\
\hline TOTAL & 2738407 & 27013 & $0.99 \%$ & 1685418 & 6064 & $0.36 \%$ & 1873228 & 15435 & $0.82 \%$ & 533743 & \#\#\# & $2.21 \%$ & 350336 & 3451 & $0.99 \%$ & 146643 & 5588 & $3.81 \%$ & 699006 & 9743 & $1.39 \%$ \\
\hline
\end{tabular}


Table 3. Total number of backward citations to EPO patents and their equivalents by year.

\begin{tabular}{|c|c|c|c|c|c|c|c|c|c|c|c|c|c|c|c|c|}
\hline & \multicolumn{3}{|c|}{ Brazil } & \multicolumn{3}{|c|}{ China } & \multicolumn{3}{|c|}{ India } & \multicolumn{3}{|c|}{ Mexico } & \multicolumn{3}{|c|}{ Russia } & \multirow{2}{*}{\begin{tabular}{|l|}
\multicolumn{1}{|c|}{ So } \\
National \\
Only
\end{tabular}} \\
\hline & $\begin{array}{l}\text { Domestic } \\
\text { Only }\end{array}$ & $\begin{array}{l}\text { Domestic } \\
\text { Only } \\
(\%)\end{array}$ & Total & $\begin{array}{l}\text { Domestic } \\
\text { Only }\end{array}$ & $\begin{array}{l}\text { Domestic } \\
\text { Only } \\
(\%)\end{array}$ & Total & $\begin{array}{l}\text { Domestic } \\
\text { Only }\end{array}$ & $\begin{array}{l}\text { Domestic Only } \\
(\%)\end{array}$ & Total & Domestic Only & $\begin{array}{l}\text { Domestic Only } \\
(\%)\end{array}$ & Total & Domestic Only & $\begin{array}{l}\text { Domestic Only } \\
(\%)\end{array}$ & Total & \\
\hline 1990 & 3 & $3,7 \%$ & 81 & 1 & $1,6 \%$ & 63 & 10 & $14,9 \%$ & 67 & 2 & $8,0 \%$ & 25 & 6 & $8,1 \%$ & 74 & 15 \\
\hline 1991 & 7 & $8,1 \%$ & 86 & 4 & $5,3 \%$ & 76 & 5 & $6,3 \%$ & 79 & 1 & $12,5 \%$ & 8 & 2 & $1,4 \%$ & 141 & 12 \\
\hline 1992 & 1 & $0,9 \%$ & 113 & 3 & $3,0 \%$ & 99 & 2 & $3,9 \%$ & 51 & 0 & $0,0 \%$ & 39 & 8 & $3,7 \%$ & 219 & 46 \\
\hline 1993 & 1 & $0,7 \%$ & 139 & 7 & $3,4 \%$ & 205 & 0 & $0,0 \%$ & 113 & 3 & $4,0 \%$ & 75 & 14 & $3,7 \%$ & 378 & 31 \\
\hline 1994 & 4 & $3,8 \%$ & 105 & 4 & $3,4 \%$ & 119 & 2 & $1,7 \%$ & 117 & 0 & $0,0 \%$ & 57 & 13 & $3,2 \%$ & 401 & 20 \\
\hline 1995 & 6 & $3,4 \%$ & 174 & 4 & $2,1 \%$ & 194 & 3 & $2,7 \%$ & 113 & 4 & $5,3 \%$ & 75 & 34 & $6,2 \%$ & 546 & 13 \\
\hline 1996 & 3 & $2,1 \%$ & 145 & 9 & $4,4 \%$ & 204 & 3 & $1,4 \%$ & 208 & 4 & $3,6 \%$ & 112 & 48 & $8,7 \%$ & 553 & 19 \\
\hline 1997 & 9 & $3,1 \%$ & 287 & 16 & $4,0 \%$ & 404 & 9 & $3,5 \%$ & 256 & 6 & $3,2 \%$ & 185 & 46 & $7,5 \%$ & 612 & 69 \\
\hline 1998 & 8 & $1,4 \%$ & 567 & 7 & $1,5 \%$ & 480 & 18 & $5,3 \%$ & 341 & 5 & $2,9 \%$ & 172 & 81 & $7,9 \%$ & 1031 & 62 \\
\hline 1999 & 13 & $2,6 \%$ & 493 & 24 & $3,2 \%$ & 753 & 31 & $4,4 \%$ & 711 & 6 & $4,1 \%$ & 146 & 61 & $8,5 \%$ & 719 & 42 \\
\hline 2000 & 14 & $4,2 \%$ & 335 & 40 & $3,4 \%$ & 1181 & 45 & $6,5 \%$ & 688 & 7 & $5,1 \%$ & 138 & 61 & $8,9 \%$ & 684 & 49 \\
\hline 2001 & 16 & $4,7 \%$ & 341 & 43 & $3,5 \%$ & 1226 & 61 & $8,0 \%$ & 760 & 3 & $1,6 \%$ & 182 & 71 & $11,7 \%$ & 608 & 37 \\
\hline 2002 & 9 & $3,5 \%$ & 255 & 59 & $4,3 \%$ & 1370 & 66 & $6,5 \%$ & 1012 & 8 & $5,9 \%$ & 135 & 45 & $9,7 \%$ & 463 & 22 \\
\hline 2003 & 19 & $8,7 \%$ & 218 & 48 & $2,7 \%$ & 1798 & 63 & $6,8 \%$ & 921 & 5 & $4,8 \%$ & 105 & 37 & $8,9 \%$ & 418 & 25 \\
\hline 2004 & 7 & $8,5 \%$ & 82 & 25 & $3,1 \%$ & 808 & 19 & $6,2 \%$ & 306 & 1 & $2,7 \%$ & 37 & 9 & $6,8 \%$ & 132 & 3 \\
\hline
\end{tabular}

Table 4. Average number of domestic inventors per EPO patent in the BRICSM (only BRICSM invented patents)

\begin{tabular}{lccc}
\hline & $1990-1994$ & $1995-1999$ & $2000-2004$ \\
Brazil & $71 \%$ & $60 \%$ & $75 \%$ \\
China & $59 \%$ & $65 \%$ & $74 \%$ \\
India & $59 \%$ & $71 \%$ & $78 \%$ \\
Mexico & $49 \%$ & $56 \%$ & $60 \%$ \\
Russia & $83 \%$ & $76 \%$ & $73 \%$ \\
South Africa & $87 \%$ & $79 \%$ & $81 \%$ \\
\hline
\end{tabular}


Table 5. Geographical distribution of EPO patents before and after Trips. Number of patents and shares by region

\begin{tabular}{|c|c|c|c|c|c|c|c|c|c|c|c|c|c|c|c|c|c|c|c|c|}
\hline \multirow[b]{3}{*}{ Brazil } & \multicolumn{4}{|c|}{$\begin{array}{l}\text { Only national co- } \\
\text { inventors }\end{array}$} & \multicolumn{4}{|c|}{ Other BRICSM } & \multicolumn{4}{|c|}{ Us } & \multicolumn{4}{|c|}{ eu4 } & \multicolumn{4}{|c|}{ Japan } \\
\hline & \multicolumn{2}{|c|}{$90-96$} & \multicolumn{2}{|c|}{$97-03$} & \multicolumn{2}{|c|}{$90-96$} & \multicolumn{2}{|c|}{$97-03$} & \multicolumn{2}{|c|}{$90-96$} & \multicolumn{2}{|c|}{$97-03$} & \multicolumn{2}{|c|}{$90-96$} & \multicolumn{2}{|c|}{$97-03$} & \multicolumn{2}{|c|}{$90-96$} & \multicolumn{2}{|c|}{$97-03$} \\
\hline & 394 & $73,5 \%$ & 1025 & $73,5 \%$ & 3 & $0,6 \%$ & 4 & $0,3 \%$ & 43 & $8,0 \%$ & 126 & $9,0 \%$ & 70 & $13,1 \%$ & 149 & $10,7 \%$ & 2 & $0,4 \%$ & 8 & $0,6 \%$ \\
\hline China & 382 & $67,6 \%$ & 3257 & $74,5 \%$ & 4 & $0,7 \%$ & 5 & $0,1 \%$ & 74 & $13,1 \%$ & 473 & $10,8 \%$ & 43 & $7,6 \%$ & 229 & $5,2 \%$ & 26 & $4,6 \%$ & 65 & $1,5 \%$ \\
\hline India & 283 & $64,5 \%$ & 2038 & $73,8 \%$ & 2 & $0,5 \%$ & 3 & $0,1 \%$ & 87 & $19,8 \%$ & 390 & $14,1 \%$ & 42 & $9,6 \%$ & 161 & $5,8 \%$ & 6 & $1,4 \%$ & 15 & $0,5 \%$ \\
\hline Mexico & 161 & $63,9 \%$ & 411 & $66,1 \%$ & 1 & $0,4 \%$ & 3 & $0,5 \%$ & 52 & $20,6 \%$ & 113 & $18,2 \%$ & 17 & $6,7 \%$ & 61 & $9,8 \%$ & 2 & $0,8 \%$ & 3 & $0,5 \%$ \\
\hline Russia & 1006 & $71,8 \%$ & 1846 & $66,8 \%$ & 2 & $0,1 \%$ & 5 & $0,2 \%$ & 103 & $7,3 \%$ & 300 & $10,9 \%$ & 136 & $9,7 \%$ & 306 & $11,1 \%$ & 15 & $1,1 \%$ & 25 & $0,9 \%$ \\
\hline S. Africa & 642 & $84,5 \%$ & 1055 & $83,1 \%$ & 4 & $0,5 \%$ & 2 & $0,2 \%$ & 24 & $3,2 \%$ & 57 & $4,5 \%$ & 64 & $8,4 \%$ & 94 & $7,4 \%$ & 1 & $0,1 \%$ & 1 & $0,1 \%$ \\
\hline
\end{tabular}

Table 6. Number of backward citations to EPO patents by destination country (and shares) before and after Trips

\begin{tabular}{|c|c|c|c|c|c|c|c|c|c|c|c|c|c|c|c|c|c|c|c|c|}
\hline \multirow[b]{3}{*}{ Brazil } & \multicolumn{4}{|c|}{ national citations } & \multicolumn{4}{|c|}{ Other BRICSM } & \multicolumn{4}{|c|}{ Us } & \multicolumn{4}{|c|}{ eu4 } & \multicolumn{4}{|c|}{ Japan } \\
\hline & \multicolumn{2}{|c|}{$90-96$} & \multicolumn{2}{|c|}{$97-03$} & \multicolumn{2}{|c|}{$90-96$} & \multicolumn{2}{|c|}{$97-03$} & \multicolumn{2}{|c|}{$90-96$} & \multicolumn{2}{|c|}{$97-03$} & \multicolumn{2}{|c|}{$90-96$} & \multicolumn{2}{|c|}{$97-03$} & \multicolumn{2}{|c|}{$90-96$} & \multicolumn{2}{|c|}{$97-03$} \\
\hline & 25 & $3,0 \%$ & 95 & $3,7 \%$ & 2 & $0,2 \%$ & 24 & $0,9 \%$ & 282 & $33,5 \%$ & 777 & $30,3 \%$ & 307 & $36,5 \%$ & 959 & $37,4 \%$ & 82 & $9,7 \%$ & 277 & $10,8 \%$ \\
\hline China & 32 & $3,3 \%$ & 262 & $3,3 \%$ & 3 & $0,3 \%$ & 31 & $0,4 \%$ & 319 & $33,2 \%$ & 2634 & $33,0 \%$ & 282 & $29,4 \%$ & 1994 & $25,0 \%$ & 199 & $20,7 \%$ & 1333 & $16,7 \%$ \\
\hline India & 25 & $3,4 \%$ & 312 & $6,3 \%$ & 5 & $0,7 \%$ & 37 & $0,7 \%$ & 280 & $37,8 \%$ & 1743 & $35,1 \%$ & 221 & $29,9 \%$ & 1303 & $26,2 \%$ & 102 & $13,8 \%$ & 683 & $13,7 \%$ \\
\hline Mexico & 14 & $3,6 \%$ & 41 & $3,8 \%$ & 2 & $0,5 \%$ & 9 & $0,8 \%$ & 153 & $39,2 \%$ & 404 & $37,0 \%$ & 135 & $34,6 \%$ & 349 & $31,9 \%$ & 31 & $7,9 \%$ & 97 & $8,9 \%$ \\
\hline Russia & 125 & $5,4 \%$ & 411 & $8,9 \%$ & 4 & $0,2 \%$ & 25 & $0,5 \%$ & 697 & $30,2 \%$ & 1641 & $35,3 \%$ & 715 & $31,0 \%$ & 1239 & $26,7 \%$ & 402 & $17,4 \%$ & 610 & $13,1 \%$ \\
\hline S. Africa & 156 & $10,2 \%$ & 309 & $12,0 \%$ & 6 & $0,4 \%$ & 13 & $0,5 \%$ & 419 & $27,4 \%$ & 700 & $27,3 \%$ & 521 & $34,1 \%$ & 644 & $25,1 \%$ & 145 & $9,5 \%$ & 200 & $7,8 \%$ \\
\hline
\end{tabular}




\section{Table 7 . Descriptive Statistics}

\begin{tabular}{|c|c|c|c|c|c|c|}
\hline Variable & Definition & Obs & Mean & Std. Dev. & Min & $\operatorname{Max}$ \\
\hline Collaborative patents & $\begin{array}{l}\text { Number of EPO patents with at least an inventor } \\
\text { from country } i \text { (emerging) and country } j \\
\text { (advanced)where the weight of domestic inventors } \\
\text { is at least } 20 \% \text { of the. }\end{array}$ & 595 & 5.33 & 11.68 & 0 & 127 \\
\hline Patent citations & $\begin{array}{l}\text { Number of EPO citations made by patents of } \\
\text { country } i \text { to patents of country } j \text { in year } t \text {. }\end{array}$ & 595 & 17.82 & 30.42 & 0 & 270 \\
\hline $\ln$ PATENTS $_{i t}$ & $\begin{array}{l}\text { Number of EPO patent applications in year } t \text { with } \\
\text { at least an inventor residing in country } i \text { and } j\end{array}$ & 595 & 4.66 & .95 & 2.70 & 7.13 \\
\hline $\ln \mathrm{GDP}_{i t}$ & Millions of constant US dollars, (year 2000 prices) & 595 & 12.89 & .68 & 11.58 & 14.35 \\
\hline $\ln \mathrm{GDP}_{i t}$ & (in logarithm). & 595 & 28.25 & .84 & 26.99 & 29.99 \\
\hline $\ln \mathrm{IMP}_{i j t}$ & $\begin{array}{l}\text { Bilateral imports, millions of US dollars, current } \\
\text { prices (in logarithm). }\end{array}$ & 595 & 7.62 & 1.19 & 1.79 & 11.62 \\
\hline $\ln \mathrm{FDI}_{i t}$ & $\begin{array}{l}\text { Inward - millions of constant US dollars, (year } 2000 \\
\text { prices) (in logarithm). }\end{array}$ & 595 & 8.31 & 2.01 & 0 & 11.01 \\
\hline $\ln$ DISTANCE $_{i j}$ & $\begin{array}{l}\mathrm{Km} \text {, simple distance which uses latitudes and } \\
\text { longitudes of the most important } \\
\text { cities/agglomerations (in terms of population) (in } \\
\text { logarithm). }\end{array}$ & 595 & 8.94 & .50 & 7.63 & 9.82 \\
\hline $\mathrm{ORIG}_{i j}$ & $\begin{array}{l}\text { Dummy which equals to one if the two countries } \\
\text { have a common legal origin }\end{array}$ & 595 & .25 & .43 & 0 & 1 \\
\hline $\mathrm{TP}_{i j t}$ & Indicator of pairwise "technological proximity" & 595 & .68 & .12 & .26 & .94 \\
\hline $\ln \mathrm{IPR}_{i t}$ & $\begin{array}{l}\text { Ginarte and Park Index (Ginarte and Park, 1997; } \\
\text { Park 2008) (in logarithm). }\end{array}$ & 595 & .83 & .48 & .02 & 1.44 \\
\hline TRIPS $_{t}$ & $\begin{array}{l}\text { Dummy equals to one if } \mathrm{t} \geq 1996 \text { and zero } \\
\text { elsewhere. }\end{array}$ & 595 & .63 & .48 & 0 & 1 \\
\hline
\end{tabular}


Table 8. The impact of IPRs on Collaborative Patents: BRICSM Countries

\begin{tabular}{|c|c|c|c|c|c|}
\hline VARIABLES & $\begin{array}{c}{[1]} \\
\text { POISSON }\end{array}$ & $\begin{array}{c}{[2]} \\
\text { POISSON }\end{array}$ & $\begin{array}{c}{[3]} \\
\text { POISSON }\end{array}$ & $\begin{array}{c}{[4]} \\
\text { POISSON } \\
\text { FE } \\
\end{array}$ & $\begin{array}{c}{[5]} \\
\text { POISSON } \\
\text { FE } \\
\end{array}$ \\
\hline $\ln$ PATENTS $_{i t}$ & $\begin{array}{c}0.82 * * * \\
(0.11)\end{array}$ & $\begin{array}{c}0.78^{* * *} \\
(0.11)\end{array}$ & $\begin{array}{c}0.77 * * * \\
(0.11)\end{array}$ & $\begin{array}{c}0.76^{* * *} \\
(0.084)\end{array}$ & $\begin{array}{c}0.76^{* * * *} \\
(0.085)\end{array}$ \\
\hline${ }_{\ln \text { PATENTS }_{i t}}$ & $\begin{array}{c}0.20 \\
(0.36)\end{array}$ & $\begin{array}{c}0.34 \\
(0.41)\end{array}$ & $\begin{array}{c}0.63 \\
(0.68)\end{array}$ & $\begin{array}{c}0.38 \\
(0.35)\end{array}$ & $\begin{array}{c}0.47 \\
(0.47)\end{array}$ \\
\hline $\ln \mathrm{GDP}_{i t}$ & $\begin{array}{l}-0.33 \\
(0.31)\end{array}$ & $\begin{array}{l}-0.50 \\
(0.36)\end{array}$ & $\begin{array}{l}-0.38 \\
(0.40)\end{array}$ & $\begin{array}{l}-0.23 \\
(0.32)\end{array}$ & $\begin{array}{l}-0.20 \\
(0.33)\end{array}$ \\
\hline $\ln \mathrm{GDP}_{j t}$ & $\begin{array}{c}1.09 \\
(0.78)\end{array}$ & $\begin{array}{l}1.35^{*} \\
(0.78)\end{array}$ & $\begin{array}{l}1.73^{*} \\
(0.91)\end{array}$ & $\begin{array}{l}1.39 * * \\
(0.59)\end{array}$ & $\begin{array}{l}1.50^{* *} \\
(0.71)\end{array}$ \\
\hline $\ln \operatorname{IMP}_{i j t}$ & & $\begin{array}{l}0.19^{*} \\
(0.11)\end{array}$ & $\begin{array}{l}0.19^{*} \\
(0.11)\end{array}$ & $\begin{array}{l}-0.027 \\
(0.076)\end{array}$ & $\begin{array}{l}-0.023 \\
(0.077)\end{array}$ \\
\hline $\ln \mathrm{FDI}_{i t}$ & & $\begin{array}{l}-0.062 \\
(0.049)\end{array}$ & $\begin{array}{l}-0.048 \\
(0.050)\end{array}$ & $\begin{array}{l}-0.048 \\
(0.036)\end{array}$ & $\begin{array}{l}-0.044 \\
(0.038)\end{array}$ \\
\hline $\ln$ DISTANCE $_{i j}$ & $\begin{array}{c}-0.39 * * * \\
(0.061)\end{array}$ & $\begin{array}{l}-0.11 \\
(0.19)\end{array}$ & $\begin{array}{l}-0.11 \\
(0.19)\end{array}$ & & \\
\hline $\mathrm{ORIG}_{i j}$ & $\begin{array}{c}0.50^{* * * *} \\
(0.14)\end{array}$ & $\begin{array}{c}0.47^{* * * *} \\
(0.15)\end{array}$ & $\begin{array}{c}0.47 * * * \\
(0.15)\end{array}$ & & \\
\hline $\mathrm{TP}_{i t}$ & $\begin{array}{c}1.70^{* * *} \\
(0.31)\end{array}$ & $\begin{array}{c}1.51 * * * \\
(0.32)\end{array}$ & $\begin{array}{c}1.51 * * * \\
(0.32)\end{array}$ & $\begin{array}{c}0.95^{* * *} \\
(0.34)\end{array}$ & $\begin{array}{c}0.95^{* * * *} \\
(0.34)\end{array}$ \\
\hline $\ln \mathrm{IPR}_{i t}$ & $\begin{array}{l}-0.056 \\
(0.16)\end{array}$ & $\begin{array}{l}-0.062 \\
(0.15)\end{array}$ & $\begin{array}{l}-0.016 \\
(0.16)\end{array}$ & $\begin{array}{c}0.0080 \\
(0.14)\end{array}$ & $\begin{array}{l}0.021 \\
(0.14)\end{array}$ \\
\hline TRIPS $_{\mathrm{t}}$ & & & $\begin{array}{l}-0.52 \\
(0.73)\end{array}$ & & $\begin{array}{l}-0.16 \\
(0.54)\end{array}$ \\
\hline Constant & $\begin{array}{l}-28.6 \\
(18.6) \\
\end{array}$ & $\begin{array}{c}-37.4^{* *} \\
(18.3) \\
\end{array}$ & $\begin{array}{l}-51.1^{*} \\
(26.4) \\
\end{array}$ & & \\
\hline Observations & 595 & 595 & 595 & 595 & 595 \\
\hline Year dummy & Yes & Yes & Yes & Yes & Yes \\
\hline Country i dummy & Yes & Yes & Yes & No & No \\
\hline Country $j$ dummy & Yes & Yes & Yes & No & No \\
\hline Log likelihood & -1098.10 & -1090.35 & -1089.87 & -875.50 & -875.46 \\
\hline
\end{tabular}


Table 9. The impact of Trips on Patent Citations

\begin{tabular}{|c|c|c|c|c|c|}
\hline VARIABLES & $\begin{array}{c}{[1]} \\
\text { POISSON }\end{array}$ & $\begin{array}{c}{[2]} \\
\text { POISSON }\end{array}$ & $\begin{array}{c}{[3]} \\
\text { POISSON }\end{array}$ & $\begin{array}{c}{[4]} \\
\text { POISSON } \\
\text { FE }\end{array}$ & $\begin{array}{c}{[5]} \\
\text { POISSON } \\
\text { FE }\end{array}$ \\
\hline${ }_{\text {ln } \text { PATENTS }_{i t}}$ & $\begin{array}{l}1.27 * * * \\
(0.070)\end{array}$ & $\begin{array}{l}1.25^{* * *} \\
(0.069)\end{array}$ & $\begin{array}{l}1.16^{* * *} \\
(0.069)\end{array}$ & $\begin{array}{c}1.24 * * * \\
(0.048)\end{array}$ & $\begin{array}{l}1.15^{* * *} \\
(0.049)\end{array}$ \\
\hline $\ln$ PATENTS $_{i t}$ & $\begin{array}{c}-1.15^{* * *} \\
(0.43)\end{array}$ & $\begin{array}{c}-0.82^{*} \\
(0.47)\end{array}$ & $\begin{array}{c}1.00^{* *} \\
(0.47)\end{array}$ & $\begin{array}{c}-0.89 * * * \\
(0.20)\end{array}$ & $\begin{array}{c}0.91 * * * \\
(0.27)\end{array}$ \\
\hline $\ln \mathrm{GDP}_{i t}$ & $\begin{array}{c}-0.75^{* * *} \\
(0.28)\end{array}$ & $\begin{array}{c}-0.88^{* * *} \\
(0.27)\end{array}$ & $\begin{array}{l}0.013 \\
(0.27)\end{array}$ & $\begin{array}{c}-0.61 \text { *** } \\
(0.18)\end{array}$ & $\begin{array}{c}0.15 \\
(0.20)\end{array}$ \\
\hline $\ln \mathrm{GDP}_{j t}$ & $\begin{array}{c}-1.14^{* *} \\
(0.54)\end{array}$ & $\begin{array}{l}-0.91 \\
(0.56)\end{array}$ & $\begin{array}{l}0.94 * \\
(0.56)\end{array}$ & $\begin{array}{c}-0.78^{* * *} \\
(0.30)\end{array}$ & $\begin{array}{c}1.04 * * * \\
(0.34)\end{array}$ \\
\hline $\ln \mathrm{IMP}_{i j t}$ & & $\begin{array}{c}0.094 * * \\
(0.038)\end{array}$ & $\begin{array}{c}0.084^{* *} \\
(0.036)\end{array}$ & $\begin{array}{l}-0.059 \\
(0.045)\end{array}$ & $\begin{array}{l}-0.0044 \\
(0.045)\end{array}$ \\
\hline $\ln \mathrm{FDI}_{i t}$ & & $\begin{array}{c}-0.078^{* *} \\
(0.032)\end{array}$ & $\begin{array}{c}0.018 \\
(0.024)\end{array}$ & $\begin{array}{c}-0.073^{* * *} \\
(0.016)\end{array}$ & $\begin{array}{c}0.016 \\
(0.018)\end{array}$ \\
\hline $\ln$ DISTANCE $_{i j}$ & $\begin{array}{c}-0.13^{* * *} \\
(0.027)\end{array}$ & $\begin{array}{l}-0.028 \\
(0.055)\end{array}$ & $\begin{array}{l}-0.053 \\
(0.053)\end{array}$ & & \\
\hline ORIG $_{i j}$ & $\begin{array}{c}0.19^{* * *} \\
(0.060)\end{array}$ & $\begin{array}{c}0.20^{* * *} \\
(0.054)\end{array}$ & $\begin{array}{c}0.21 * * * \\
(0.049)\end{array}$ & & \\
\hline $\mathrm{TP}_{i j t}$ & $\begin{array}{c}0.22 \\
(0.29)\end{array}$ & $\begin{array}{l}0.098 \\
(0.27)\end{array}$ & $\begin{array}{c}0.12 \\
(0.24)\end{array}$ & $\begin{array}{c}-0.54^{* * *} \\
(0.19)\end{array}$ & $\begin{array}{c}-0.43^{* *} \\
(0.19)\end{array}$ \\
\hline $\ln \mathrm{IPR}_{i t}$ & $\begin{array}{c}-0.24^{*} \\
(0.15)\end{array}$ & $\begin{array}{c}-0.25^{*} \\
(0.14)\end{array}$ & $\begin{array}{c}0.11 \\
(0.12)\end{array}$ & $\begin{array}{c}-0.21^{* * *} \\
(0.080)\end{array}$ & $\begin{array}{c}0.12 \\
(0.086)\end{array}$ \\
\hline $\begin{array}{l}\text { TRIPS }_{\mathrm{t}} \\
\text { Constant }\end{array}$ & $44.0^{* * *}$ & $36.4^{* * *}$ & $\begin{array}{c}-3.31 * * * \\
(0.45) \\
-37.4^{* *}\end{array}$ & & $\begin{array}{c}-3.21 * * * \\
(0.29)\end{array}$ \\
\hline & $(12.6)$ & $(13.3)$ & $(17.1)$ & & \\
\hline Observations & 595 & 595 & 595 & 595 & 595 \\
\hline Year dummy & Yes & Yes & Yes & Yes & Yes \\
\hline Country i dummy & Yes & Yes & Yes & No & No \\
\hline Country j dummy & Yes & Yes & Yes & No & No \\
\hline Log likelihood & -1741.87 & -1725.30 & -1655.97 & -1529.23 & -1467.63 \\
\hline
\end{tabular}


Figure 1. Share of total patents by technological class (patents by inventors, years: 1990-2004)

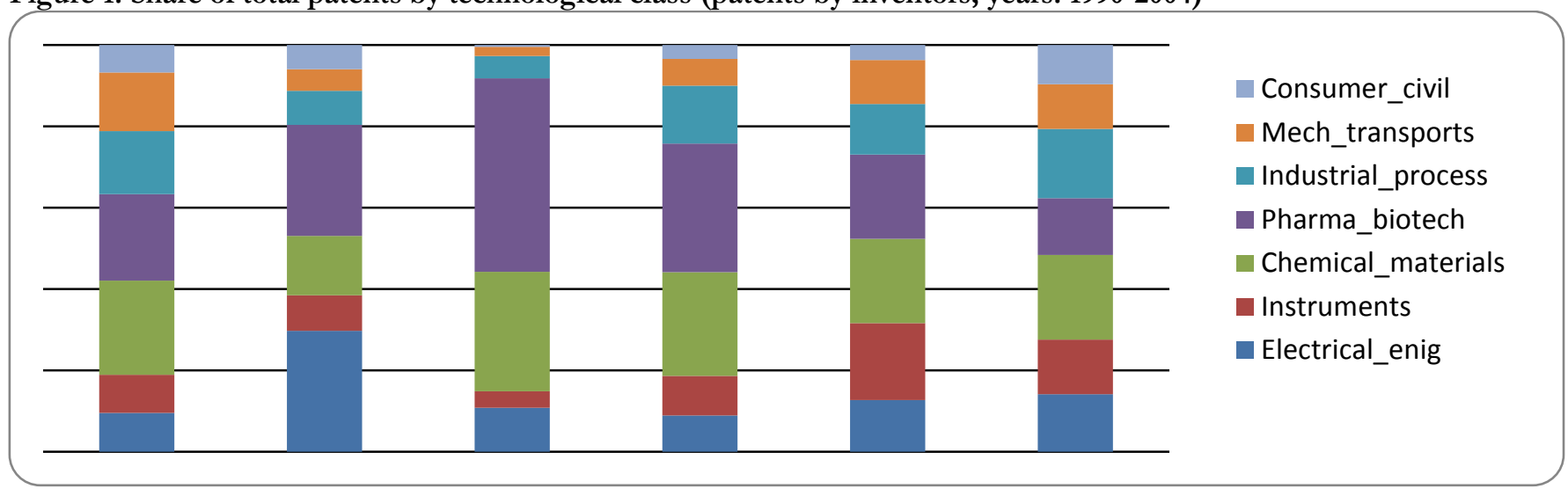

Figure 2. Share of collaborative patents by technological class (patents by inventors, years: 1990-2004)

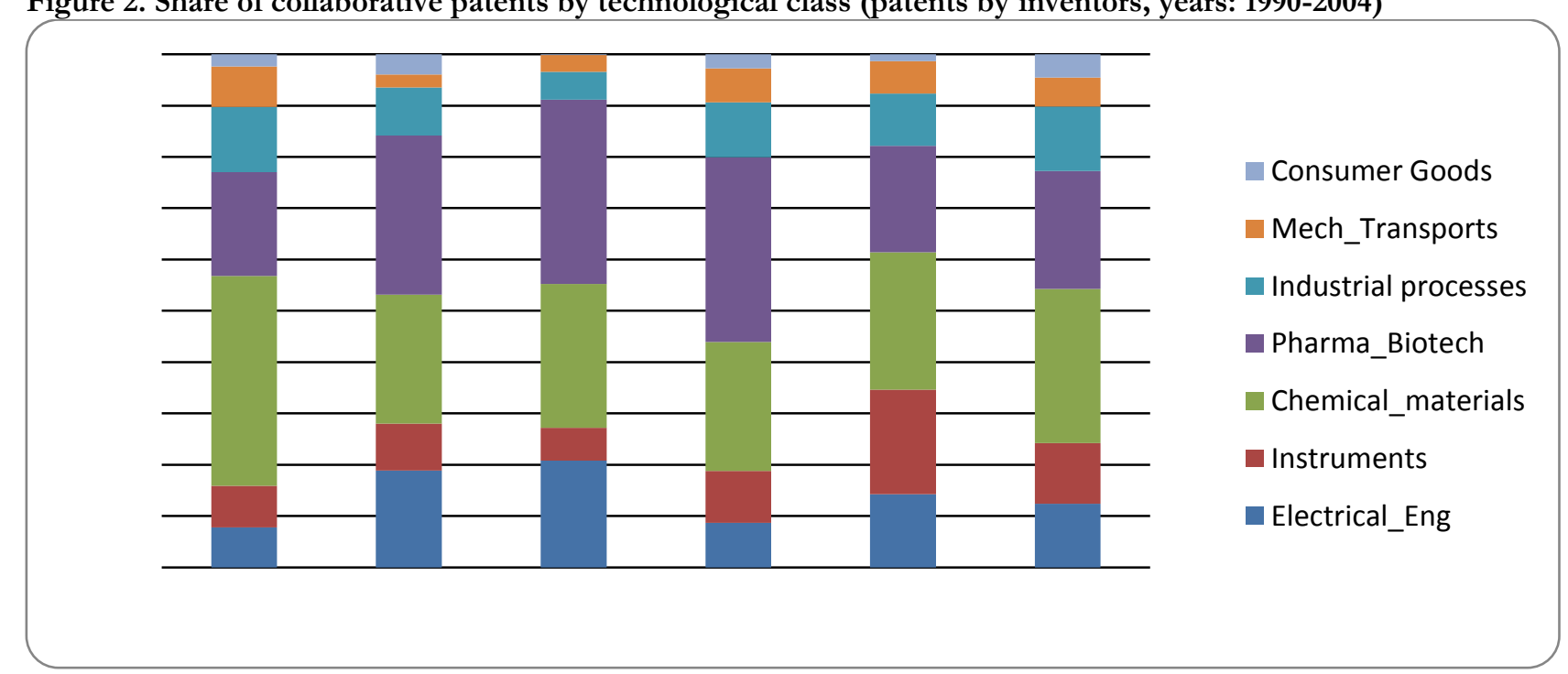




\section{APPENDIX}

Table A1. Number of collaborative patents and number of (real) collaborative patents with at least $20 \%$ of domestic inventors in the inventors' team (EPO patents).

\begin{tabular}{|c|c|c|c|c|c|c|c|c|c|c|c|c|c|c|c|c|c|c|}
\hline & & BRAZIL & & & CHINA & & & INDIA & & & MEXICO & & & RUSSIA & & $\mathrm{SOL}$ & UTH AFR & ICA \\
\hline year & $\begin{array}{l}\text { Collabor } \\
\text { ative }\end{array}$ & $\begin{array}{l}\text { Real } \\
\text { Collabor } \\
\text { ative }\end{array}$ & $\%$ Real & $\begin{array}{l}\text { Collabor } \\
\text { ative }\end{array}$ & $\begin{array}{l}\text { Real } \\
\text { Collabor } \\
\text { ative }\end{array}$ & $\%$ Real & $\begin{array}{l}\text { Collabor } \\
\text { ative }\end{array}$ & $\begin{array}{l}\text { Real } \\
\text { Collabor } \\
\text { ative }\end{array}$ & $\%$ Real & $\begin{array}{l}\text { Collabor } \\
\text { ative }\end{array}$ & $\begin{array}{l}\text { Real } \\
\text { Collabor } \\
\text { ative }\end{array}$ & $\%$ Real & $\begin{array}{l}\text { Collabor } \\
\text { ative }\end{array}$ & $\begin{array}{l}\text { Real } \\
\text { Collabor } \\
\text { ative }\end{array}$ & $\%$ Real & $\begin{array}{l}\text { Collabor } \\
\text { ative }\end{array}$ & $\begin{array}{l}\text { Real } \\
\text { Collabor } \\
\text { ative }\end{array}$ & $\%$ Real \\
\hline 1990 & 10 & 9 & $90 \%$ & 9 & 7 & $78 \%$ & 17 & 13 & $76 \%$ & 5 & 5 & $100 \%$ & 4 & 4 & $100 \%$ & 8 & 8 & $100 \%$ \\
\hline 1991 & 9 & 8 & $89 \%$ & 13 & 10 & $77 \%$ & 10 & 9 & $90 \%$ & 2 & 2 & $100 \%$ & 13 & 13 & $100 \%$ & 8 & 7 & $88 \%$ \\
\hline 1992 & 16 & 12 & $75 \%$ & 18 & 10 & $56 \%$ & 13 & 13 & $100 \%$ & 7 & 6 & $86 \%$ & 29 & 29 & $100 \%$ & 12 & 11 & $92 \%$ \\
\hline 1993 & 14 & 11 & $79 \%$ & 26 & 15 & $58 \%$ & 26 & 15 & $58 \%$ & 16 & 13 & $81 \%$ & 39 & 39 & $100 \%$ & 18 & 18 & $100 \%$ \\
\hline 1994 & 12 & 10 & $83 \%$ & 18 & 12 & $67 \%$ & 21 & 12 & $57 \%$ & 14 & 12 & $86 \%$ & 56 & 52 & $93 \%$ & 9 & 8 & $89 \%$ \\
\hline 1995 & 34 & 26 & $76 \%$ & 31 & 23 & $74 \%$ & 20 & 13 & $65 \%$ & 17 & 15 & $88 \%$ & 53 & 49 & $92 \%$ & 20 & 17 & $85 \%$ \\
\hline 1996 & 24 & 17 & $71 \%$ & 36 & 33 & $92 \%$ & 32 & 22 & $69 \%$ & 11 & 8 & $73 \%$ & 70 & 61 & $87 \%$ & 15 & 12 & $80 \%$ \\
\hline 1997 & 26 & 19 & $73 \%$ & 55 & 40 & $73 \%$ & 25 & 21 & $84 \%$ & 22 & 15 & $68 \%$ & 74 & 71 & $96 \%$ & 19 & 15 & $79 \%$ \\
\hline 1998 & 66 & 23 & $35 \%$ & 49 & 40 & $82 \%$ & 53 & 39 & $74 \%$ & 24 & 21 & $88 \%$ & 87 & 80 & $92 \%$ & 26 & 16 & $62 \%$ \\
\hline 1999 & 31 & 15 & $48 \%$ & 67 & 49 & $73 \%$ & 72 & 62 & $86 \%$ & 26 & 23 & $88 \%$ & 105 & 91 & $87 \%$ & 24 & 15 & $63 \%$ \\
\hline 2000 & 36 & 25 & $69 \%$ & 136 & 93 & $68 \%$ & 69 & 45 & $65 \%$ & 22 & 16 & $73 \%$ & 100 & 88 & $88 \%$ & 37 & 36 & $97 \%$ \\
\hline 2001 & 51 & 38 & $75 \%$ & 128 & 98 & $77 \%$ & 77 & 60 & $78 \%$ & 27 & 25 & $93 \%$ & 101 & 92 & $91 \%$ & 22 & 20 & $91 \%$ \\
\hline 2002 & 33 & 30 & $91 \%$ & 166 & 117 & $70 \%$ & 109 & 95 & $87 \%$ & 31 & 24 & $77 \%$ & 87 & 75 & $86 \%$ & 18 & 13 & $72 \%$ \\
\hline 2003 & 46 & 36 & $78 \%$ & 216 & 174 & $81 \%$ & 178 & 141 & $79 \%$ & 34 & 28 & $82 \%$ & 101 & 90 & $89 \%$ & 17 & 13 & $76 \%$ \\
\hline 2004 & 69 & 55 & $80 \%$ & 243 & 169 & $70 \%$ & 186 & 142 & $76 \%$ & 34 & 23 & $68 \%$ & 93 & 82 & $88 \%$ & 27 & 23 & $85 \%$ \\
\hline TOTAL & 477 & 334 & $70 \%$ & 1211 & 890 & $73 \%$ & 908 & 702 & $77 \%$ & 292 & 236 & $81 \%$ & 1012 & 916 & $91 \%$ & 280 & 232 & $83 \%$ \\
\hline
\end{tabular}


Table A2. Co-applicant: relationship by typology of applicant. Number of co-applied patents and percentage by typology of institution (EPO patents).

\begin{tabular}{|c|c|c|c|c|c|c|c|c|c|c|c|c|}
\hline \multirow{2}{*}{$\begin{array}{l}\text { Co-applicant relationship } \\
\text { Individual-Individual }\end{array}$} & Brazil & $90-96$ & \multicolumn{2}{|c|}{${ }_{04}^{\text {Brazil }}$} & \multirow{2}{*}{$\begin{array}{c}\text { China } \\
20\end{array}$} & \multirow{2}{*}{$\begin{array}{l}\text { 90-96 } \\
59 \%\end{array}$} & \multirow{2}{*}{$\begin{array}{c}\text { China } \\
57\end{array}$} & \multirow{2}{*}{$\begin{array}{l}\text { 97-04 } \\
35 \%\end{array}$} & \multirow{2}{*}{$\begin{array}{l}\text { India } \\
7\end{array}$} & \multirow{2}{*}{$\begin{array}{l}\text { 90-96 } \\
50 \%\end{array}$} & \multirow{2}{*}{$\begin{array}{c}\text { India } \\
55\end{array}$} & \multirow{2}{*}{$\begin{array}{l}\text { 97-04 } \\
34 \%\end{array}$} \\
\hline & 1 & $25 \%$ & 19 & $40 \%$ & & & & & & & & \\
\hline Individual-University & 0 & $0 \%$ & 0 & $0 \%$ & 0 & $0 \%$ & 1 & $1 \%$ & 0 & $0 \%$ & 2 & $1 \%$ \\
\hline Individual-Company & 0 & $0 \%$ & 4 & $9 \%$ & 1 & $3 \%$ & 14 & $9 \%$ & 0 & $0 \%$ & 24 & $15 \%$ \\
\hline University-Individual & 0 & $0 \%$ & 0 & $0 \%$ & 2 & $6 \%$ & 0 & $0 \%$ & 0 & $0 \%$ & 0 & $0 \%$ \\
\hline University-University & 1 & $25 \%$ & 2 & $4 \%$ & 0 & $0 \%$ & 8 & $5 \%$ & 0 & $0 \%$ & 0 & $0 \%$ \\
\hline University-Company & 0 & $0 \%$ & 2 & $4 \%$ & 6 & $18 \%$ & 14 & $9 \%$ & 0 & $0 \%$ & 3 & $2 \%$ \\
\hline Company-Individual & 0 & $0 \%$ & 5 & $11 \%$ & 0 & $0 \%$ & 4 & $2 \%$ & 0 & $0 \%$ & 5 & $3 \%$ \\
\hline Company-University & 0 & $0 \%$ & 2 & $4 \%$ & 0 & $0 \%$ & 2 & $1 \%$ & 0 & $0 \%$ & 0 & $0 \%$ \\
\hline Company-Company & 2 & $50 \%$ & 13 & $28 \%$ & 5 & $15 \%$ & 64 & $39 \%$ & 7 & $50 \%$ & 71 & $44 \%$ \\
\hline Total & 4 & $100 \%$ & 47 & $100 \%$ & 34 & $100 \%$ & 164 & $100 \%$ & 14 & $100 \%$ & 160 & $100 \%$ \\
\hline Co-applicant relationship & Mexico & $90-96$ & & $\begin{array}{l}\text { xico } \\
04\end{array}$ & & & & & $\begin{array}{r}\text { Sout } \\
9\end{array}$ & $\begin{array}{l}\text { Africa } \\
96\end{array}$ & $\begin{array}{r}\text { Sout } \\
9\end{array}$ & $\begin{array}{l}\text { Africa } \\
04\end{array}$ \\
\hline Individual-Individual & 1 & $20 \%$ & 7 & $37 \%$ & 33 & $32 \%$ & 71 & $48 \%$ & 7 & $35 \%$ & 16 & $33 \%$ \\
\hline Individual-University & 0 & $0 \%$ & 1 & $5 \%$ & 0 & $0 \%$ & 0 & $0 \%$ & 0 & $0 \%$ & 1 & $2 \%$ \\
\hline Individual-Company & 0 & $0 \%$ & 2 & $11 \%$ & 8 & $8 \%$ & 23 & $16 \%$ & 1 & $5 \%$ & 3 & $6 \%$ \\
\hline University-Individual & 0 & $0 \%$ & 0 & $0 \%$ & 2 & $2 \%$ & 4 & $3 \%$ & 0 & $0 \%$ & 0 & $0 \%$ \\
\hline University-University & 0 & $0 \%$ & 2 & $11 \%$ & 0 & $0 \%$ & 0 & $0 \%$ & 1 & $5 \%$ & 4 & $8 \%$ \\
\hline University-Company & 1 & $20 \%$ & 1 & $5 \%$ & 15 & $15 \%$ & 12 & $8 \%$ & 1 & $5 \%$ & 4 & $8 \%$ \\
\hline Company-Individual & 0 & $0 \%$ & 1 & $5 \%$ & 1 & $1 \%$ & 3 & $2 \%$ & 3 & $15 \%$ & 6 & $13 \%$ \\
\hline Company-University & 0 & $0 \%$ & 0 & $0 \%$ & 0 & $0 \%$ & 0 & $0 \%$ & 0 & $0 \%$ & 3 & $6 \%$ \\
\hline Company-Company & 3 & $60 \%$ & 5 & $26 \%$ & 43 & $42 \%$ & 34 & $23 \%$ & 7 & $35 \%$ & 11 & $23 \%$ \\
\hline Total & 5 & $100 \%$ & 19 & $100 \%$ & 102 & $100 \%$ & 147 & $100 \%$ & 20 & $100 \%$ & 48 & $100 \%$ \\
\hline
\end{tabular}


Table A3. Description of the database by source

\begin{tabular}{|l|l|}
\hline Variable & source \\
\hline PATENT APPLICATIONS & Ep-Kites (Patstat) Database \\
TRADE & Stan Bilateral Trade Database (GRAND TOTAL) \\
GDP & WDI Online (World Bank) \\
IPR index & Park W. (2008) \\
FDI & Unctad \\
DISTANCE & CEPII dataset \\
LEGAL ORIGIN & La Porta et al. (1998) \\
\hline
\end{tabular}

